\title{
Remediation of 4-Nitroaniline by Plaster-Based Permeable Reactive Barriers Containing Zero Valent Iron (ZVI): Precast Plaster Retaining Wall Blocks for Environmental Applications
}

saliha boudia

Universite Mouloud Mammeri de Tizi Ouzou

farida fernane

Universite Mouloud Mammeri de Tizi Ouzou

patrick j sharrock

Université Toulouse III Paul Sabatier: Universite Toulouse III Paul Sabatier

marina m.l. fiallo ( $\square$ marina.fiallo@iut-tlse3.fr)

Université Toulouse III Paul Sabatier: Universite Toulouse III Paul Sabatier https://orcid.org/0000-00017704-9388

\section{Research Article}

Keywords: groundwater remediation, zero-valent iron, nitroaniline, pollutants, plaster, precast retaining wall block

Posted Date: March 15th, 2021

DOI: https://doi.org/10.21203/rs.3.rs-281415/v1

License: (c) (i) This work is licensed under a Creative Commons Attribution 4.0 International License.

Read Full License 
1 Remediation of 4-nitroaniline by plaster-based permeable 2 reactive barriers containing zero valent iron (ZVI): precast 3 plaster retaining wall blocks for environmental applications

5 Saliha Boudia ${ }^{\mathrm{a}, \mathrm{b}}$, Farida Fernane ${ }^{\mathrm{a}}$, Patrick Sharrock ${ }^{\mathrm{b}}$, Marina Fiallo ${ }^{\mathrm{b} *}$,

6

$7 \quad{ }^{a}$ Mouloud Mammeri University, Natural Resources Laboratory, Tizi-Ouzou 15000 Algeria

$8{ }^{b}$ Chemistry department, IUT A, Université Toulouse 3 Paul Sabatier, 81104 Castres, France

9 *Corresponding author: marina.fiallo@iut-tlse3.fr, phone ++33(0)563621553

11 Keywords: groundwater remediation, zero-valent iron, nitroaniline, pollutants, plaster, 12 precast retaining wall block

\section{Graphical abstract}

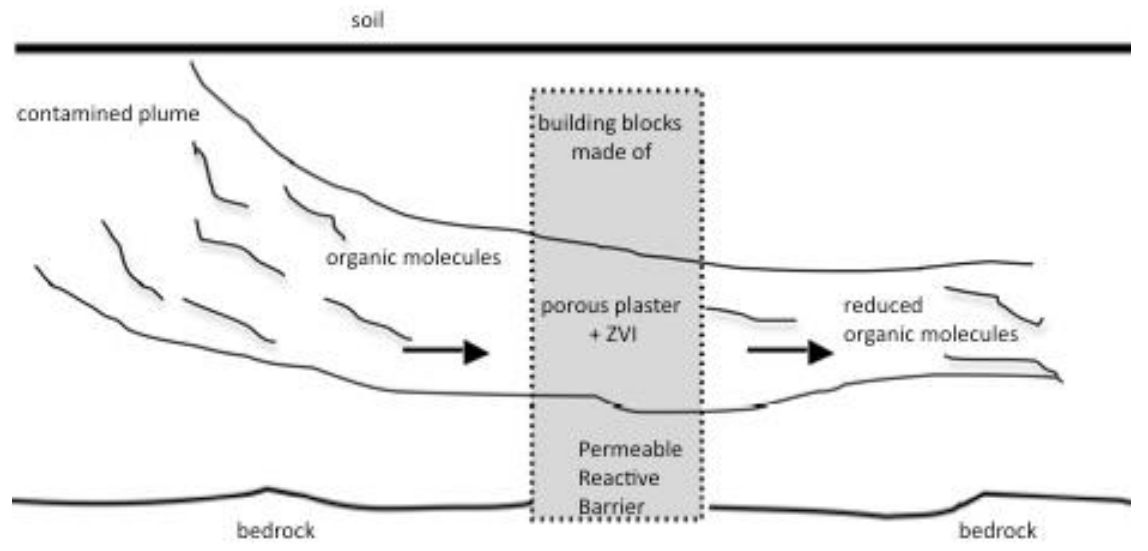

16 Highlights files

17 - Precast plaster blocks were tested for environmental applications

18 - Zero Valent Iron (ZVI) dispersed in plaster blocks was active in reducing 4-nitroaniline 19 (PNA) to p-phenylenediammine with a reactive capacity of $55 \mathrm{mg} / \mathrm{g}$ (PNA/ZVI) 
- Permeability of plaster blocks can be modulated depending on composite formulation.

22 Abbreviations: PDA, p-phenylenediamine; PE, polyethylene; PET, polyethylene terephtalate; PNA, 4-nitroaniline (or p-nitroaniline)

\section{Abstract}

Permeable reactive barrier (PRB) containing zero valent iron (ZVI), plaster and additives to make a porous composite structure was tested to remove an organic nitro compound as model pollutant. An aqueous solution of 4-nitroaniline (PNA) was passed through a porous plaster composite column and chemical degradation quantified by UV-Vis spectroscopy. PNA was reduced to p-phenylenediamine and the rate of the reduction was strongly related to ZVI amount, pollutant volume, and the contact rate with metal particles. The parameters could be controlled by reactor design and operation. The columns were made to test the materials for making precast plaster blocks containing ZVI. The results showed that such porous plaster blocks could be efficient as retaining walls for environmental applications.

\section{Introduction}

Permeable reactive barrier (PRB) is a cost-effective technology for "in situ passive method" of groundwater remediation (Henderson and Demond 2007). It is an implementation of filtration consisting in a permeable zone, which passively captures a plume of contaminants through immobilization or transformation of pollutants, releasing decontaminated water to the other side of the barrier (Grajales-Mesa and Malina 2016). PRB is generally composed of inexpensive filler materials, doped with specific reagents for remediation of unwanted compounds. It was reported that zero valent iron (ZVI) is particularly effective in chemical 
44 degradation of persistent chlorinated compounds into non-toxic and harmless by-products

45 (Dorathi and Kandasamy 2012).

46 Nitrocompounds are usually present in hair dyes (Various authors 1992), in pharmaceuticals, such as chloroamphenicol (Various authors 1989a) and metronidazole (Gavrilescu et al. 2015), and nitroarenes has been identified in vehicle exhausts (Various authors 1989).

Nitroarenes can be reduced to corresponding anilines, in presence of ZVI and hydrochloric acid, in Bechamp reduction (Béchamp 1854); moreover, in organic synthesis other methods have found to be more specific and to reduce by-pass products (Schabel et al. 2013). For instance, silver nanoparticles were developed for in situ catalytic reduction method of PNA (Farooqi et al. 2018). However, in order to integrate in PRB a low cost reactant, ZVI has already shown to be a good candidate for reduction of different pollutants ( $\mathrm{Hu}$ et al. 2018; Eljamal et al. 2018, 2020; Khalil et al. 2018; Maamoun et al. 2018, 2020, 2020a). Efficiency of PRB is related to flow of polluted plume and to pollutant characteristics (Wantanaphong et al. 2006; Touze, et al. 2004).

Calcium sulfates (including plaster, $\mathrm{CaSO}_{4} \cdot 0.5 \mathrm{H}_{2} \mathrm{O}$, and its dihydrated product, gypsum, $\mathrm{CaSO}_{4} \cdot 2 \mathrm{H}_{2} \mathrm{O}$ ) were chosen as inert substrate in order to prepare composites. They are low cost building materials, sometime considered as a waste when by-product in industrial preparation of phosphoric acid (Saadaoui et al. 2017). One great advantage of calcium sulfates is that they are compatible with a variety of fillers, still retaining adequate mechanical properties. The main problem in using them for geological applications is their

64 relative solubility, which, however, could be an advantage in an environmental approach: in 65 fact a calcium sulfate-based PRB should break up with time discharging in environment no 66 toxic species.

67 We researched the possibility of using plaster as barrier component for controlling liquid 68 flow rates while simultaneously introducing a low cost reactive material. Our aim was to 
verify if plaster can be used for permeable barrier construction and if ZVI retains its redox properties when included in a solid shell.

A plaster-based composite, shaped as a column, was formulated in order to make a model barrier to study ZVI efficiency for soluble organic species depollution, such as 4-nitroaniline as pollutant model.

Key factors of all-in-one composites design for PRB were investigated as follows:

1- Permeability of solid plaster, as inert support for PRB, was determined and a method to improve it was developed (giving "porous" plaster)

2- "Porous" plaster was tested for its mechanical properties and the better formulation 78 chosen.

3- ZVI was inserted in "porous" plaster and new composites were checked for their mechanical properties giving a formulation with a good compromise for all parameters.

4- Reduction of 4-nitroaniline was performed in batch with ZVI as in Béchamp reaction, in order to establish reaction chemical parameters (amount of reactive specie, $\mathrm{pH}$ values).

5- Degradation of 4-nitroaniline (PNA, used as model pollutant) to p-phenylenediamine

84 (PPD), was quantified by UV spectroscopy by measuring its absorbance maximum at 380 $\mathrm{nm}$.

5- Reduction of 4-nitroaniline was performed in column as a model for all-in-one PRB system: breakdown and exhaustion points were determined for specific experimental conditions.

\section{Experimental}

\subsection{Chemicals}

92 Plaster, in chemical form of $\mathrm{CaSO}_{4} \cdot 0.5 \mathrm{H}_{2} \mathrm{O}$, was a commercial powder (plaster of Paris

93 quality) from Parexlanko, France; iron powder (ZVI, 325 mesh, 99\%), $\mathrm{H}_{3} \mathrm{PO}_{4}(85 \%)$, and 
$94 \mathrm{CaCO}_{3}(99 \%)$ were from Acros (France), 4-nitroaniline (or p-nitroaniline, PNA, 98\%) and p95 phenylendiamine (PDA, 98\%) from Aldrich (France).

\section{2.2. Material characterization}

97 Solid samples were characterized by powder X-ray diffraction (XRD) with a Bruker D2 X'PertPRO diffractometer using $\mathrm{Cu} \mathrm{K \alpha}$ radiation $(40 \mathrm{kV}$ and $40 \mathrm{~mA}$ ). Crystallographic identification of $\mathrm{CaSO}_{4} \cdot 2 \mathrm{H}_{2} \mathrm{O}$ was accomplished by comparing the experimental XRD pattern

100 to COD 2300259 of gypsum standard (point group 2/m).

\subsection{Physical and mechanics tests}

102 All samples were weighted and "apparent" density calculated from geometrical parameters.

103 Indirect tensile stress diametral compression tests were carried out with a Zwick Roll Z020

104 testing machine (Zwick Roell, France) at a crosshead speed of $10 \mathrm{~mm} / \mathrm{min}$, until failure.

105 Using initial height $(\mathrm{L}[\mathrm{m}])$ and diameter $\left(\mathrm{D}\left[\mathrm{m}^{2}\right]\right)$ of each sample, and measuring the 106 reciprocated force $\left(\mathrm{F}\left[\mathrm{kg} / \mathrm{ms}^{2}\right]\right)$ from compression, indirect (or Brazilian) tensile strength, $\sigma_{\mathrm{T}}$ $107\left(\left[\mathrm{~kg} / \mathrm{m}^{2} \mathrm{~s}^{2}\right]\right)$, was calculated from its definition in equation 1 :

$$
\sigma_{7}=\frac{2 F}{\pi L D}
$$

\subsection{Porosity determination}

110 Porosity was determined from the ratio of experimental "apparent" density of each sample 111 and gypsum density, $\mathrm{CaSO}_{4} 2 \mathrm{H}_{2} \mathrm{O}, 2.308 \mathrm{~g} / \mathrm{cm}^{3}$ (CRC Handbook of Chemistry and Physics, 112 2019) with equation 2:

$$
\text { porosity (\%) }-\frac{\text { density }_{\text {exp }}}{\text { density }_{\text {g, }} \text { sum }} \times 100
$$

\subsection{Spectroscopic analysis}

115 UV-VIS spectra were used to quantify 4-nitroaniline (PNA) and p-phenylendiamine (PDA)

116 concentrations. Vis-UV spectra were recorded between 200 and $700 \mathrm{~nm}$ in aqueous solution

117 on a HP 8453 spectrophotometer with quartz cells of 0.2 and $1 \mathrm{~cm}$ of path-length. Spectra of 
118 pure 4-nitroaniline (PNA) and p-phenylendiamine (PDA) were recorded in aqueous solution

119 giving the following spectroscopic features: PNA: $380\left(\varepsilon=73.3 \mathrm{Lmol}^{-1} \mathrm{~cm}^{-1}\right), 227(35.5), 204$

120 (63.0) nm. PDA: $305\left(\varepsilon=13.7 \mathrm{Lmol}^{-1} \mathrm{~cm}^{-1}\right), 240(49.3), 210$ (58.7) nm. PNA concentrations in

121 solution were determined from absorbances measured at 380. PDA formation (following

122 mechanism of Bechamp reduction) was checked from band at $240 \mathrm{~nm}$ (PDA maximum

123 absorption).

124 2.6. Determination of PNA degradation

125 Degradation of PNA, meaning the disappearing of its characteristic absorption band at 380

$126 \mathrm{~nm})$, was calculated from the UV-Vis spectra with equation 3:

$$
\text { degradation }(\%)=\frac{\left(A_{3 \infty}-A_{600}\right)}{\left(A_{3 \infty}-A_{600}\right)} \times 100
$$

where $\mathrm{A}_{380}$ and $\mathrm{A}_{600}$ are the absorption values of each sample at the noted wavelengths, and

$\mathrm{A}^{\circ}{ }_{380}$ and $\mathrm{A}^{\circ}{ }_{700}$ the absorption values of starting solutions. Absorption values were corrected at $600 \mathrm{~nm}$ in order to avoid diffusion effects from cloudy solutions. At $380 \mathrm{~nm}$ the absorption contribution for presence of PDA in aqueous solutions was insignificant.

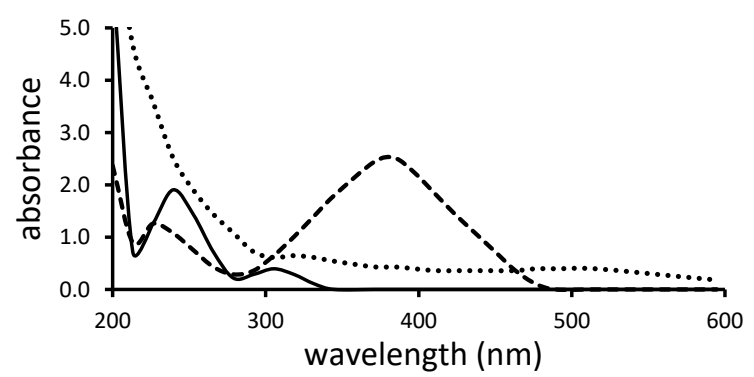

134

135 Figure 1 Absorption spectra of PNA (---), PDA (-) and PDA polymerization product (')) in aqueous solutions: $[\mathrm{PNA}]=[\mathrm{PDA}]=30 \mathrm{mg} / \mathrm{l}$; path-length quartz cell $=0.2 \mathrm{~cm}$ 
139 Plaster slabs were made by adding plaster (50 g) to appropriate amounts of distilled water.

140 After 5 minutes of mixing, preparations were poured into PET (polyethylene terephtalate) or

141 PE (polyethylene) cylindrical molds to make samples for flow experiments (in 2.8-cm-

142 diameter, 2-cm-high) and for mechanical tests and density measurements (in 2.6-cm-

143 diameter, 5-cm-heigh). All solid samples were dried at $60^{\circ} \mathrm{C}$ for 24 hours before their use.

144 2.7.1. Effect of water

145 In these series of experiment the water/plaster ratio was modified, as reported in Table 1, and

146 physical and mechanical properties measured for each sample, giving the results reported in

147 Table 1.

\begin{tabular}{|l|l|l|l|}
\hline $\begin{array}{l}\text { Water/plaster } \\
\text { ratio }(\mathrm{w} / \mathrm{w})\end{array}$ & $\begin{array}{l}\text { density } \\
(\mathrm{g} / \mathrm{ml})\end{array}$ & $\begin{array}{l}\text { porosity } \\
(\%)\end{array}$ & $\begin{array}{l}\text { indirect tensile } \\
\text { strength }(\mathrm{MPa})\end{array}$ \\
\hline 0.5 & $1.15 \pm 0.04$ & $50.46 \pm 0.40$ & $7.14 \pm 0.43$ \\
\hline 0.6 & $1.10 \pm 0.04$ & $52.71 \pm 0.33$ & $5.47 \pm 0.41$ \\
\hline 0.7 & $1.04 \pm 0.06$ & $55.06 \pm 0.61$ & $4.48 \pm 0.43$ \\
\hline 0.8 & $0.99 \pm 0.05$ & $57.39 \pm 2.00$ & $3.57 \pm 0.19$ \\
\hline
\end{tabular}

148

149 Table 1 Physical and mechanical properties of plaster samples (density, porosity, indirect

150 tensile strength) as a function of plaster/water ratio $(\mathrm{w} / \mathrm{w})$; experimental conditions: plaster

151 (50.00 g); measurements were an average from ten samples.

152 These sample were checked for their permeability (see section 2.7.5)

\subsubsection{Effect of porogen $\left(\mathrm{CaCO}_{3}+\mathrm{H}_{3} \mathrm{PO}_{4}\right)$}

154 Porous samples were prepared by grinding calcium carbonate (pure or recovered from calcined egg shell waste) with plaster powder, then pouring the powder in phosphoric acidcontaining water.

157 Permeability of these samples was compared with those of "compact" plaster (see section 2.7.5). 


\begin{tabular}{|l|l|l|l|l|}
\hline $\begin{array}{l}\mathrm{H}_{3} \mathrm{PO}_{4} \\
(\mathrm{~g})\end{array}$ & $\begin{array}{l}\mathrm{H}_{3} \mathrm{PO}_{4} \\
(\%)\end{array}$ & $\begin{array}{l}\text { density } \\
(\mathrm{g} / \mathrm{ml})\end{array}$ & $\begin{array}{l}\text { porosity } \\
(\%)\end{array}$ & $\begin{array}{l}\text { indirect tensile } \\
\text { strength (MPa) }\end{array}$ \\
\hline 0.00 & 0 & $1.04 \pm 0.06$ & $55.06 \pm 0.61$ & $4.48 \pm 0.43$ \\
\hline 0.34 & 0.3 & $0.86 \pm 0.06$ & $63.08 \pm 2.72$ & $1.48 \pm 0.09$ \\
\hline 0.68 & 0.6 & $0.76 \pm 0.01$ & $66.97 \pm 0.35$ & $1.15 \pm 0.73$ \\
\hline 1.01 & 0.8 & $0.74 \pm 0.03$ & $67.94 \pm 2.62$ & $1.04 \pm 0.25$ \\
\hline 1.35 & 1.1 & $0.72 \pm 0.01$ & $69.13 \pm 1.80$ & $0.83 \pm 0.08$ \\
\hline
\end{tabular}

159

160 Table 2 Physical and mechanical properties of plaster samples (density, porosity, indirect

161 tensile strength) as a function of $\mathrm{H}_{3} \mathrm{PO}_{4}$ added; experimental conditions: plaster (50.0g, $41.6 \%)$; water $(58.2 \%) ; \mathrm{CaCO}_{3}(0.2 \%)$

163

164

\subsubsection{Effect of acid}

165 The effect of mineral acid on plaster setting was tested with $\mathrm{H}_{3} \mathrm{PO}_{4}$ and $\mathrm{HCl}$ : if acidic

166 solutions increased porosity compared to distilled water, however samples with hydrochloric

167 acid were more dense and compact than those made with phosphoric acid (Table 3 ).

\begin{tabular}{|l|l|l|l|}
\hline acid & $\begin{array}{l}\text { density } \\
(\mathrm{g} / \mathrm{ml})\end{array}$ & $\begin{array}{l}\text { porosity } \\
(\%)\end{array}$ & $\begin{array}{l}\text { indirect tensile } \\
\text { strength }(\mathrm{MPa})\end{array}$ \\
\hline 0 & $1.04 \pm 0.06$ & $55.06 \pm 0.61$ & $4.48 \pm 0.43$ \\
\hline $\mathrm{H}_{3} \mathrm{PO}_{4}$ & $0.52 \pm 0.07$ & $77.55 \pm 0.61$ & $1.89 \pm 0.65$ \\
\hline $\mathrm{HCl}$ & $0.94 \pm 0.02$ & $59.48 \pm 0.67$ & $5.87 \pm 1.90$ \\
\hline
\end{tabular}

168

169 Table 3 Physical and mechanical properties of plaster samples (density, porosity, indirect

170 tensile strength) as a function of $\mathrm{H}_{3} \mathrm{PO}_{4}$ added; experimental conditions: plaster (50.0g,

$171 \quad 41.6 \%)$; water $(58.2 \%) ; \mathrm{CaCO}_{3}(0.2 \%)$

172 
174 Different amounts of ZVI were dispersed in solid components (plaster and calcium

175 carbonate) before adding liquid components (water and phosphoric acid), in order to 176 uniformly scatter heavy iron in slab. Physical and mechanical properties of different samples 177 obtained were reported in Table 4.

178

179

\begin{tabular}{|l|l|l|l|l|}
\hline ZVI $(\mathrm{g})$ & $\begin{array}{l}\text { ZVI percentage } \\
(\%)\end{array}$ & density $(\mathrm{g} / \mathrm{ml})$ & $\begin{array}{l}\text { porosity } \\
(\%)\end{array}$ & $\begin{array}{l}\text { indirect tensile } \\
\text { strength }(\mathrm{kPa})\end{array}$ \\
\hline 0 & 0 & $0.86 \pm 0.06$ & $63.08 \pm 2.72$ & $1.48 \pm 0.09$ \\
\hline 1.00 & 1.2 & $0.88 \pm 0.29$ & $62.19 \pm 0.66$ & $1.26 \pm 0.27$ \\
\hline 2.00 & 2.3 & $1.17 \pm 0.05$ & $49.56 \pm 0.37$ & $1.93 \pm 0.30$ \\
\hline 3.00 & 3.4 & $1.36 \pm 0.05$ & $41.23 \pm 0.93$ & $3.18 \pm 0.88$ \\
\hline 5.00 & 5.6 & $1.36 \pm 0.06$ & $41.32 \pm 0.57$ & $3.14 \pm 0.51$ \\
\hline
\end{tabular}

180 Table 4 Physical and mechanical properties of plaster samples (density, porosity, indirect 181 tensile strength) as a function of ZVI added; experimental conditions: plaster (50.0 g, 41.0\%);

182 water (57.4\%); $\mathrm{CaCO}_{3}(0.2 \%) ; \mathrm{H}_{3} \mathrm{PO}_{4}(0.2 \%)$

\subsubsection{Permeability coefficient measurements}

184 Permeability coefficient measurements were done on plaster samples (2.8-cm diameter, 2.0$\mathrm{cm}$ heigth) with a water pressure column of $5 \mathrm{~cm}$. Discharge of water $\left(\mathrm{Q}\left[\mathrm{m}^{3} / \mathrm{s}\right]\right)$ percolating under a constant head difference $(\mathrm{H}[\mathrm{m}])$ through a sample, of porous material of cross area $\mathrm{S}$ $\left(\left[\mathrm{m}^{2}\right]\right)$ and length $\mathrm{L}([\mathrm{m}])$, was determined for several samples as in Tables 5. Permeability coefficients K (hydraulic conductivity, [m/s]) were calculated from Darcy's law, following equation 4:

\begin{tabular}{|c|c|c|c|c|c|}
\hline Serie & $\begin{array}{c}\text { water/plaster } \\
(\mathrm{w} / \mathrm{w})\end{array}$ & $\begin{array}{c}\mathrm{CaCO}_{3}+\mathrm{H}_{3} \mathrm{PO}_{4} \\
(\%)\end{array}$ & $\begin{array}{c}\mathrm{ZVI} \\
(\%)\end{array}$ & $\mathrm{pH}$ values & $\begin{array}{c}\text { permeability } \\
\text { coefficient }(\mathrm{m} / \mathrm{s})\end{array}$ \\
\hline
\end{tabular}




\begin{tabular}{|c|c|c|c|c|c|}
\hline 1 & 0.7 & - & - & 7.1 & $\geq 8.2310^{-8}$ \\
\hline 2 & 0.7 & 0.4 & - & 7.4 & $2.88 \pm 0.1310^{-5}$ \\
\hline 3 & 0.7 & - & 2 & 7.1 & $\geq 8.2310^{-8}$ \\
\hline 4 & 0.7 & 0.4 & 2 & 7.3 & $2.24 \pm 0.7410^{-5}$ \\
\hline
\end{tabular}

193 Table 5 Permeability coefficients of plaster samples as a function of composition.

194 Experimental conditions: plaster (50.0 g, 41.0\%); experiments were an average of five 195 samples.

196

197 For the samples containing "compact" plaster (series 1 and 3), discharge was very slow and

198 permeability coefficients were estimated from water amount recovered after 24 hours.

199 2.7.6. Column formulation

200 In a further step, only composites with a permeability allowing to study PRB chemical 201 reactivity in period of one day, were used in depolluting tests.

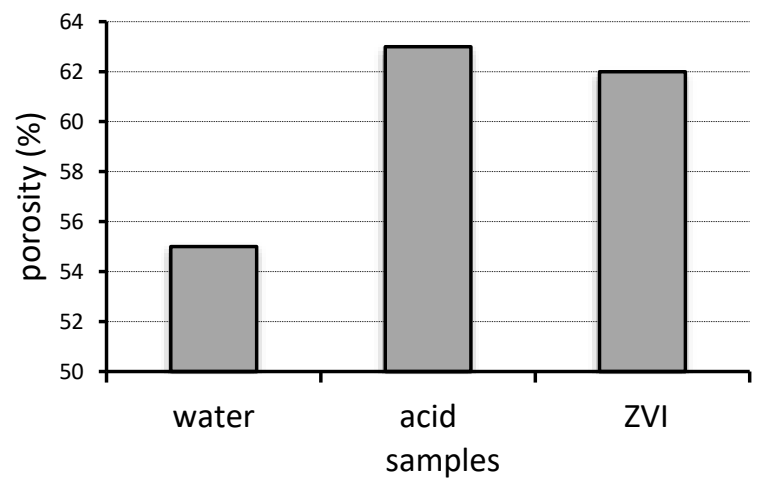

203 Figure 2 Porosity optimization as a function of different components of BRP (water, 204 phosphoric acid and ZVI) plaster (50.0 g, 40.0\%); water (56.0\%); $\mathrm{CaCO}_{3}(0.2 \%) ; \mathrm{H}_{3} \mathrm{PO}_{4}$ $205 \quad(0.2 \%)$

207 Figure 2 reported the optimization of all composite components (water, calcium carbonate, 208 phosphoric acid, ZVI) for a fixed amount of plaster in order to keep a good equilibrium 
209 between different physical properties. Final composite formulation contained plaster and 210 water with 0.7 ratio, $0.2 \% \mathrm{CaCO}_{3}$ and $0.4 \% \mathrm{H}_{3} \mathrm{PO}_{4}$ (per $50 \mathrm{~g}$ of plaster), used to mold 211 depolluting columns.

\subsection{Bechamp reduction}

2.8.1. ZVI in batch reaction

215 Batch experiments were conducted inside $250 \mathrm{ml}$ Erlemeyer flasks under continuous 216 magnetic stirring $(500 \mathrm{rpm})$ and the overall time of experiments was 7 hours. Batch 217 experimental initial conditions were: temperature; $25^{\circ} \mathrm{C}$, PNA concentration; $30 \mathrm{mg} / 1$, water volume; $100 \mathrm{ml}$. Specific variables in batch experiments included $\mathrm{pH}$ (initial $\mathrm{pH}$ acidic or neutral) and the amounts of ZVI (1, 2 and $3 \mathrm{~g})$. Sampling was conducted within accumulative

220 time of 15 minutes during first three hours, then of 1 hour for last four from commencement

221 of batch experiments, For analysis, $2 \mathrm{ml}$ samples were withdrawn by a $5 \mathrm{ml}$ syringe, Vis-UV spectra registered using a $1 \mathrm{~cm}$ quartz cell, then returned to batch. Initial $\mathrm{pH}$ was adjusted, or not, using 95\% phosphoric acid.

224 In both experiments, degradation percentage was calculated from absorbance values at 380 nm corresponding maximum absorption of PNA, as indicated in Section 2.5.

\subsubsection{Column preparation}

$100 \mathrm{~g}$ of plaster, mixed with appropriate amounts of $\mathrm{ZVI}$ and $0.2 \% \mathrm{CaCO}_{3}$, were added to 70 $\mathrm{ml}$ of distilled water, containing $0.4 \mathrm{~g}$ of phosphoric acid, then all reagents were mixed together and the viscous mixture poured into PET (polyethylene terephtalate) cylindrical molds (in 5.0-cm-diameter, 15-cm-heigh) used as percolator system. PET shells were

231 thermally fixed to plaster columns in order to avoid leaking out from their extremities.

$232 \quad$ 2.8.3. ZVI in column reaction

233 PNA-containing aqueous solutions (100 $\mathrm{ml}$ aliquots) were passed by percolation through 234 columns. Fractions of $100 \mathrm{ml}$ were recovered post-column: $2 \mathrm{ml}$ of each fraction was checked 
by UV-Vis spectrum between 200 and $700 \mathrm{~nm}$ and absorbance values at $380 \mathrm{~nm}$ (wavelength

236 of maximum absorbance for PNA) used to calculate PNA concentration in each fraction, as

237 indicated in Section 2.5.

238 2.9. SEM Analysis

239 Plaster samples were observed by scanning electron microscopy (SEM) Zeiss Supra 55VP.
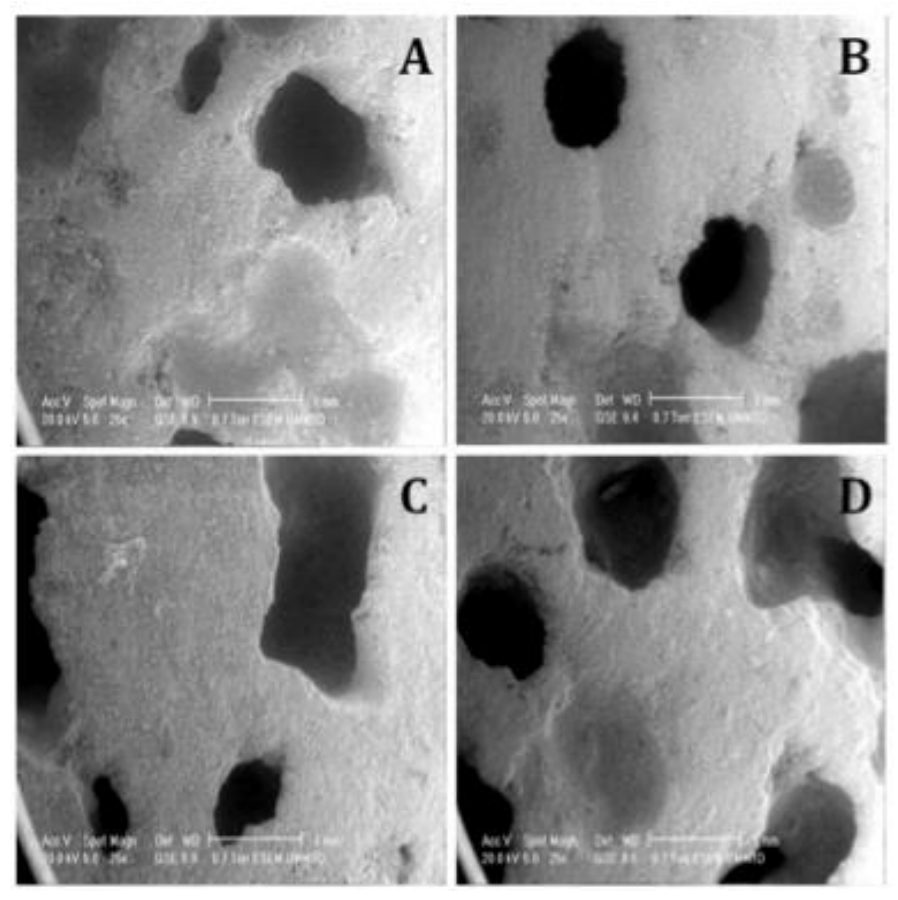

242 Figure 3 SEM photographs showing a view of porogen-containing hardened gypsum

243 samples, prepared with a water-to-plaster ratio of 0.7 , as a function of carbonate amounts

244 (with $1.1 \%$ phosphoric acid, w/w). $\mathrm{CaCO}_{3}: \mathrm{A}=0.2 \%, \mathrm{~B}=0.5 \mathrm{~g}, \mathrm{C}=0.7 \mathrm{~g}, \mathrm{D}=0.9 \%(\mathrm{w} / \mathrm{w}$ );

245 length scale bar is $1 \mathrm{~mm}$ and magnification $\mathrm{x} 25$ )

\subsection{Speciation of ZVI reacting species}

248 Samples of plaster-based composites $(2.8-\mathrm{cm}$ diameter, $2.0-\mathrm{cm}$ heigth) were soaked in

249 distilled water $(25 \mathrm{ml})$ and $\mathrm{pH}$ was measured as a function of time. O-phenathroline $(0.5 \%)$

250 and $\mathrm{KSCN}(1 \%)$ in aqueous solution were used to check presence of $\mathrm{Fe}(\mathrm{II})$ or $\mathrm{Fe}(\mathrm{III})$ species, 
respectively. Because of the low amount of iron species in solution, reagents were used in strong excess but quantification was not reliable.

\section{Results and discussion}

255 Calcium sulfates (including starting material, plaster, $\mathrm{CaSO}_{4} \cdot 0.5 \mathrm{H}_{2} \mathrm{O}$, and its hydrated product, gypsum, $\mathrm{CaSO}_{4} 2 \mathrm{H}_{2} \mathrm{O}$ ) were chosen as inert substrate in order to prepare porous composites. They are low cost materials, sometime considered as a waste as in the case of phosphogypsum (Chernysh et al. 2021) compatible with a variety of fillers, still retaining adequate mechanical properties. The main problem in using them for geological applications is their relative solubility, which could be an advantage for environmental approach: in fact a

261 calcium sulfate-based PRB should break up with time discharging in environment only no 262 toxic species.

263 Hemihydrate calcium phosphate $\left(\mathrm{CaSO}_{4} 0.5 \mathrm{H}_{2} \mathrm{O}\right)$, named plaster, became gypsum when hydrated $\left(\mathrm{CaSO}_{4} 2 \mathrm{H}_{2} \mathrm{O}\right)$; however plaster denomination was here extended to "hydrated samples", with no reference to their chemical state. Different formulations were prepared, by using plaster, water, chemical porogen and "reactive components" (ZVI) in different proportions. For each sample, density, porosity, permeability, and mechanical properties were determined.

\subsubsection{Properties of plaster-based composites}

270 It was reported that water amount determined porosity in plasters blocks (Lewry and

271 Williamson 1994; Adrien et al. 2016); as reported in Table 1, density and indirect tensile

272 strength of materials were reduced as a function of water contents and porosity increased.

273 In reaction between plaster $\left(\mathrm{CaSO}_{4}{ }^{\circ} 0.5 \mathrm{H}_{2} \mathrm{O}\right)$ and water to form gypsum $\left(\mathrm{CaSO}_{4} 2 \mathrm{H}_{2} \mathrm{O}\right)$, part of

274 water is consumed by hydration reaction during material setting and remainder slowly 
evaporated leading to porosity (Diaga Seck et al. 2015); hardening of plaster paste leads to porous structure, made of entangled needle-shape gypsum crystals (Jaffel et al. 2006). However, in order to allow percolation in short times, porosity, as shown in Table 5, obtained only by water evaporation was not enough to have an acceptable permeability and a better porogen for plaster was sought.

280 Calcium carbonate was used as porogen in presence of acid in order to generate open porosity and increase permeability through the column (Table 2); phosphoric acid was chosen because eventual formation of calcium phosphate as secondary product was supposed to not modify plaster structure: the two materials are perfectly compatible, moreover giving composites with lower dissolution rates and enhanced mechanical properties (Fisher et al. 2012).

In presence of increasing amount of $\mathrm{H}_{3} \mathrm{PO}_{4}$, porosity increased when density and mechanical properties decreased, in agreement with cavity formation following $\mathrm{CO}_{2}$ degassing during material setting (Table 2). Starting from $0.5 \%$ acid, porosity was not significantly modified, as well as mechanical properties. However, permeability increased three times of magnitude compared to "compact" plaster. Calcium phosphates, probably formed, was dispersed in gypsum matrix with no effects on physical and mechanical parameters. It was reported that weak acids (such as citric acid) play a role as plastifier, retarding setting (Lanzóna and García-Ruiz 2012) because citric acid partially inhibits binder hydration from hemihydrate to dihydrate.

294 Compatibility of $\mathrm{CaCO}_{3}$ in plaster (up to $1.5 \%$ ) was checked in order to verify density and porosity of composites. Moreover, if total porosity seemed little affected by increasing amount of $\mathrm{CaCO}_{3}$, pore dimensions were bigger (Figure 3). In SEM images of porogencontaining samples in Figure 3, presence of $1 \mathrm{~mm}$ pores of diameter was evident.

A ${ }^{1} \mathrm{H}$ NMR relaxation study of water, confined in porous medium of hardening gypsum, described coexistence of two water populations, in permeable and disordered porous plaster

300 structure (in gypsum chemical form). Regarding spatial localization of the two water 
301 populations, the first one (P1) extends uniformly in space while the second one (P2) is more 302 confined and isolated in some clusters of gypsum needles (Jaffel et al. 2006). Distribution of 303 the two populations is related to $\mathrm{w} / \mathrm{p}$ values and at low $\mathrm{w} / \mathrm{p}$ value, $\mathrm{P} 2$ increased and $\mathrm{P} 1$ 304 decreased, in agreement with total porosity observed as a function of water-to-plaster ratio 305 (w/p). Moreover, from a microstructural point of view, an intricated percolation networks of needles with different packing density exists in hardened plaster structure where percolation

307 threshold for allowing water exchange is about $\mathrm{w} / \mathrm{p}=0.6$ : below $\mathrm{w} / \mathrm{p}=0.6$, there is an 308 extremely slow exchange rate (almost zero) and the two water populations are almost 309 independent. Above $\mathrm{w} / \mathrm{p}=0.7$, there is a small but finite exchange rate between the two water 310 populations, however composite permeability was not sufficient to run PRB kinetic studies in 311 short times.

312 Presence of mineral acids influence gypsum crystallization step, promoting formation of large 313 bulky crystals (Mori 1982). Because of increasing in particle size due to increased growth 314 rate (Al-Othman and Demopoulos 2009), strength of hydrochloric acid-containing samples 315 was increased and their porosity similar to samples in absence of acid (Table 3), However, 316 goal of our research was to increase plaster permeability in order to accelerate degradation 317 reactions and not to ameliorate composite mechanical properties. For these reasons 318 hydrochloric acid was not used in further experiments.

319 It has to be observed that in the absence of carbonate, porosity was higher with respect to 320 samples in Table 2, indicating that $\mathrm{CaCO}_{3}$ could also act as buffer to stop the acid reactivity 321 and control porosity. However, if porosity of different plaster slabs, as numeric values 322 obtained from sample densities, with and without porogen, was not so different (62\% vs $55 \%$, 323 Table 4), permeability was extremely dependent on porogen nature, differing about three 324 orders of magnitude (Table 5). 


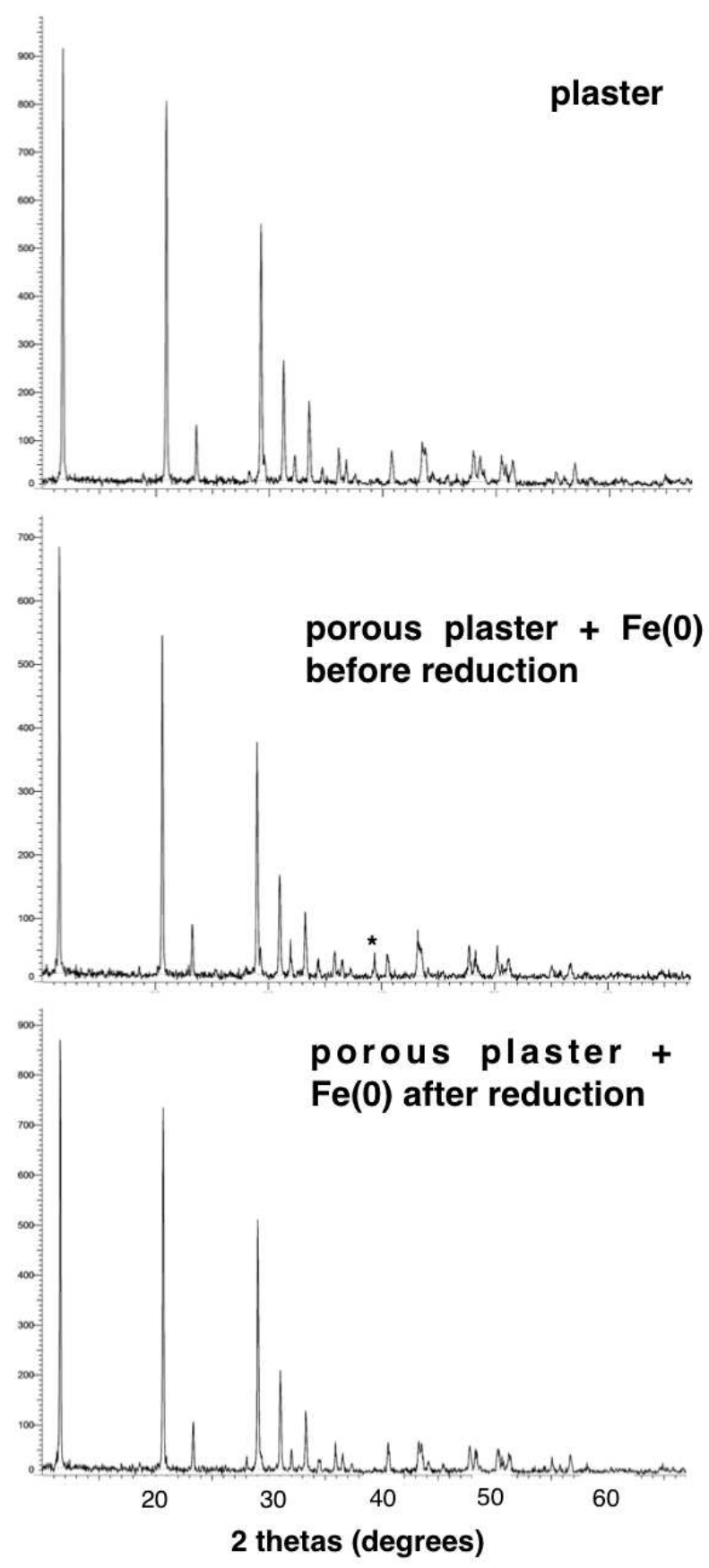

Depending on ZVI amounts (Table 4), density and mechanical properties were increased, porosity was reduced whereas, however permeability remained similar than in absence of ZVI.

\subsubsection{Composite characterization}

XRD diffractograms for plaster samples (Figure 4) were compatible with those of gypsum (COD 2300259). For composites, porous, with and without ZVI, all chemicals other than calcium sulfate were less than $10 \%$ and major deflection angle at $44.8^{\circ}$ (2ө) for $\mathrm{Fe}(0)$ (Khalil et al. 2018) not detected by XRD. In fact, in these experimental condition, it could be observed, mixed to gypsum, only with

$34250 \% \mathrm{Fe}(0)$. However, in composites containing $\mathrm{Fe}(0)$ a deflection angle at $39.5^{\circ}$ was present

343 but disappeared after PNA reduction (Figure 4) indicating presence of reactive iron species 344 not clearly identified by DRX data. 
362 Figure 4 DRX of plaster composites, with and without $\mathrm{Fe}(0)$, before and after PNA

363 reduction. Composites were formulated as in Tables 1 and 4

364

365 3.2. Chemical reduction (Bechamp reduction)

366 3.2.1. ZVI reactivity in batch reduction

367 In order to identify the best experimental conditions, Bechamp reduction was checked 368 batchwise. Experiments were run as a function of ZVI amount, in absence and in presence of 369 phosphoric acid to activate reduction. "Classical” Bechamp reduction (Béchamp 1854) is run

370 with acetic acid (or hydrochloric acid), which does not form insoluble species after oxidation 371 of ZVI to $\mathrm{Fe}(\mathrm{II})$ or $\mathrm{Fe}(\mathrm{III})$; in fact possible formation of insoluble iron phosphate was

372 expected in our experimental conditions, however nothing was reported in literature to 373 support its role in Bechamp reduction. As a function of time, yellow solution turned pale: 374 also in absence of acid, reduction occurred and after 7 hours almost no PNA remained in 375 solution (Figure 5). 


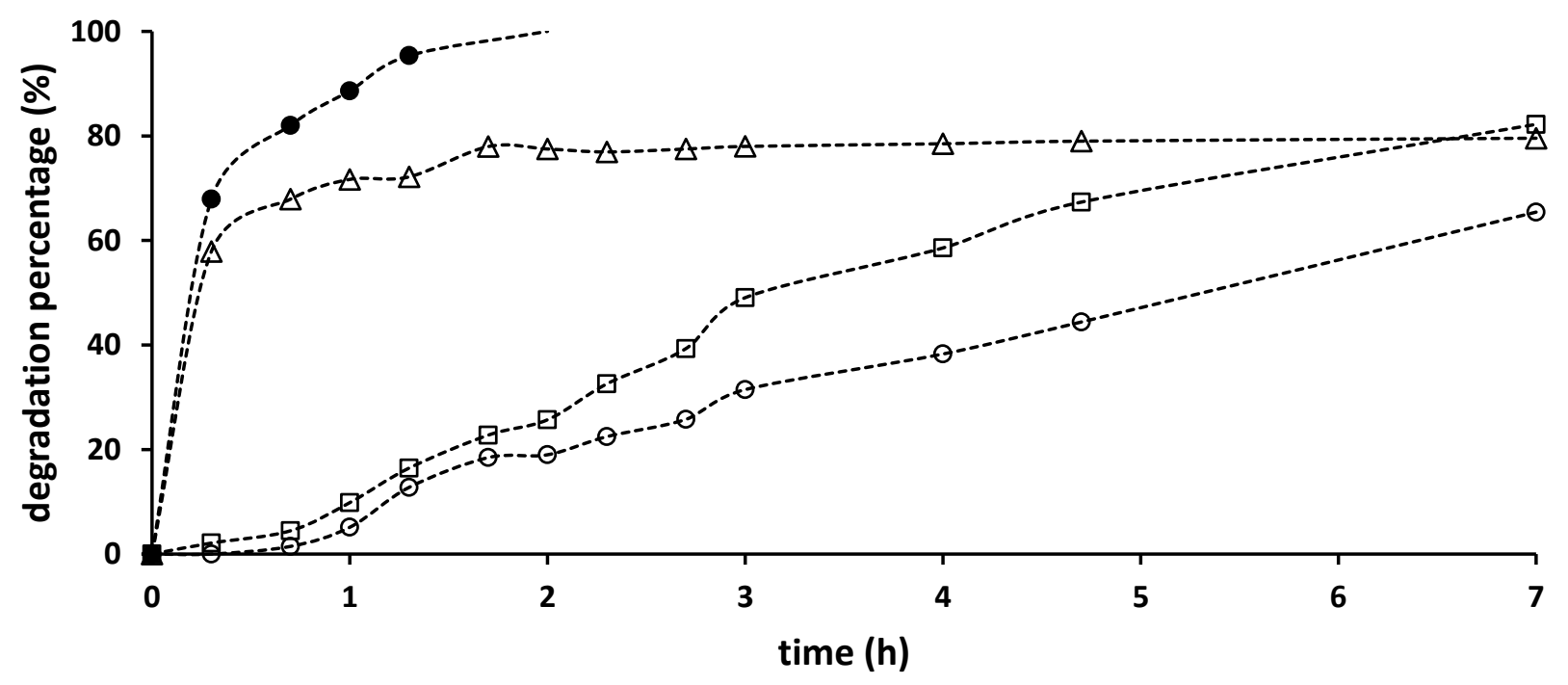

376

377 Figure 5 Degradation of PNA in Bechamp reduction as a function of time and of ZVI

378 percentage: $1.2(\bigcirc) ; 2.3(\square) ; 3.4(\triangle) ; 1.0 \%+1.0 \% \mathrm{H}_{3} \mathrm{PO}_{4}(\bullet) ;[\mathrm{PNA}]=30 \mathrm{mg} / 1$

380 In presence of $\mathrm{H}_{3} \mathrm{PO}_{4}(0.4 \%)$ or higher amount of ZVI $(>3 \%)$, the reaction was faster and total

381 reduction occurred in 1 hour. Samples recovered after reduction, with or without acid,

382 became violet by standing and solutions were cloudy: the presence in solution of ionic iron

383 species can form insoluble iron hydroxydes (even if at acidic $\mathrm{pH}$, Figure 6) which explained

384 cloudy diffusion. Redox reaction was not halted to PDA and polymerization of aromatic

385 molecules also occurred, as usual in presence of metal ions (Lajoie-Halova et al. 2006;

386 Sapurina and Stejskal 2008). In addition, formation of iron hydroxo species seemed justified

387 because $\mathrm{pH}$ values increased at the end of Bechamp reduction, in all experimental conditions

388 (Figure 6).

389 


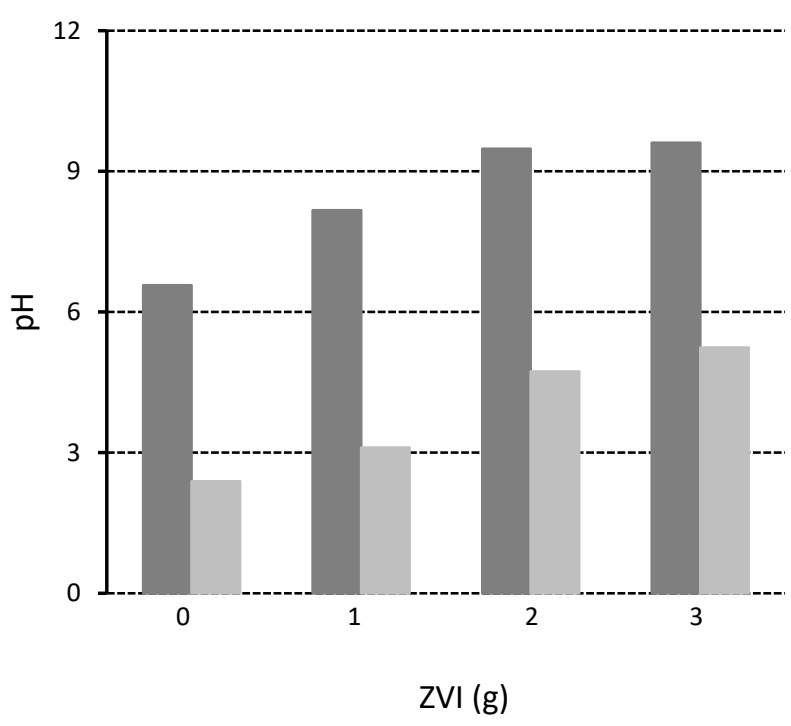

391 Figure 6 Final $\mathrm{pH}$ values of solutions in batch Bechamp reduction after 7 hours, as a fonction 392 of ZVI: without acid (dark grey); with $1 \% \mathrm{H}_{3} \mathrm{PO}_{4}$ (light grey)

394 3.2.2. ZVI reactivity in column reduction

395 PNA solutions were added to columns (Fig. 7) and, after percolation, fractions (100 ml) were 396 recovered and analyzed by Vis-UV spectroscopy. In all experiments, yellow colour of PNA 397 solutions disappeared indicating that Bechamp reduction occurred in plaster columns. In 398 order to verify chemical effects in colour fading, UV-Vis spectra were registered between 399200 and $700 \mathrm{~nm}$ : PNA was reduced to PDA indicating that Bechamp reaction occurred in 400 plaster column (Figure 1). As observed in batch experiments, PDA aqueous solutions were 401 not stable as a function of time and pale yellow solutions became hazy and violet colored, 402 indicating polymerization of aromatic amines. 


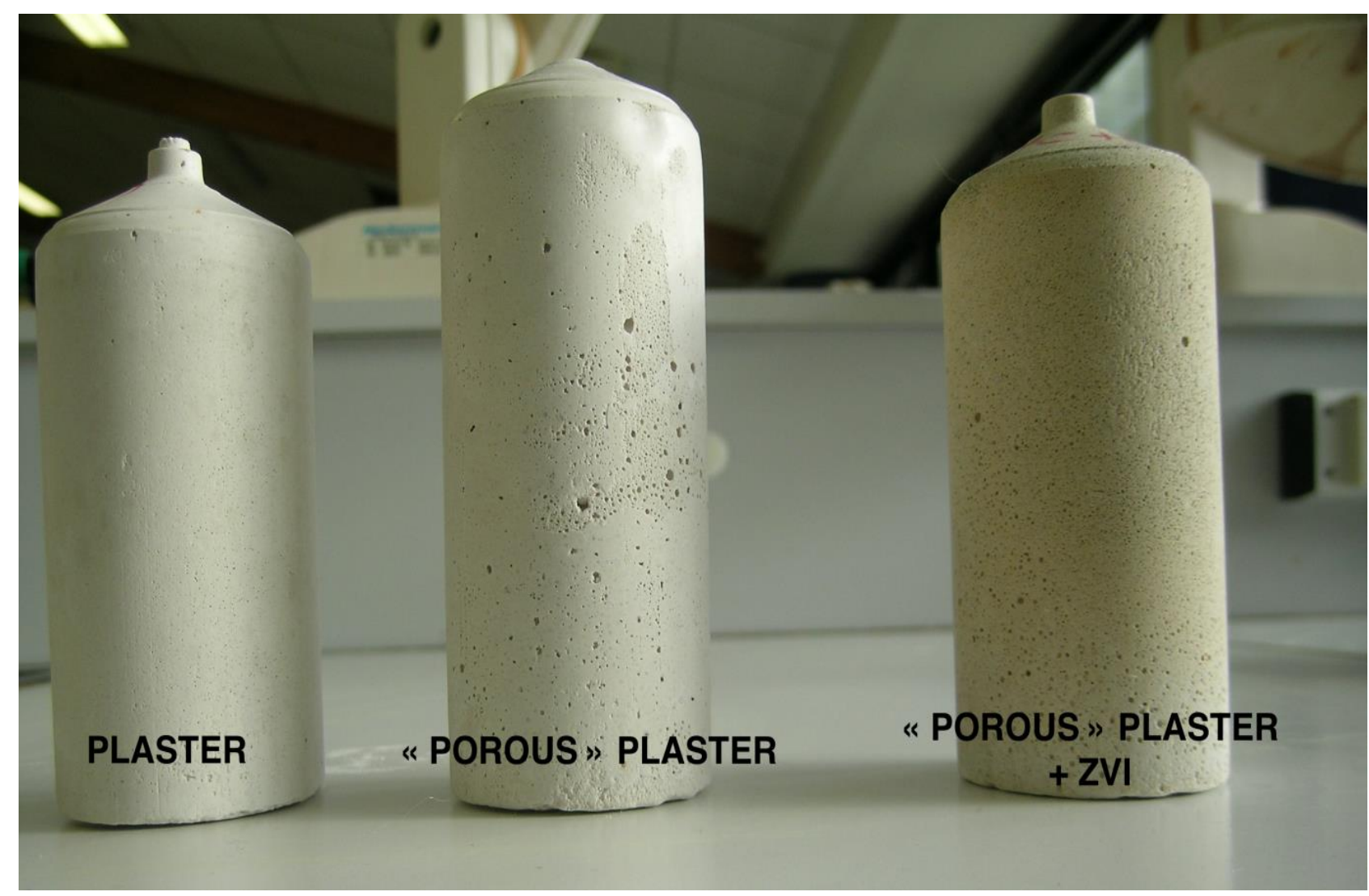

404 Figure 7 Plaster columns. Column composition: plaster (50.0 g, 41.0\%); water (57.4\%); $405 \mathrm{CaCO}_{3}(0.2 \%) ; \mathrm{H}_{3} \mathrm{PO}_{4}(1.4 \%) ; \mathrm{ZVI}(2.3 \%)$

406 Degradation profiles, as a function of time at different concentration of PNA and ZVI, were 407 reported in Figure 8. The flow through the columns was around $0.3 \mathrm{ml} / \mathrm{min}$ and increased as a 408 function of added volume at about $25 \%$ 

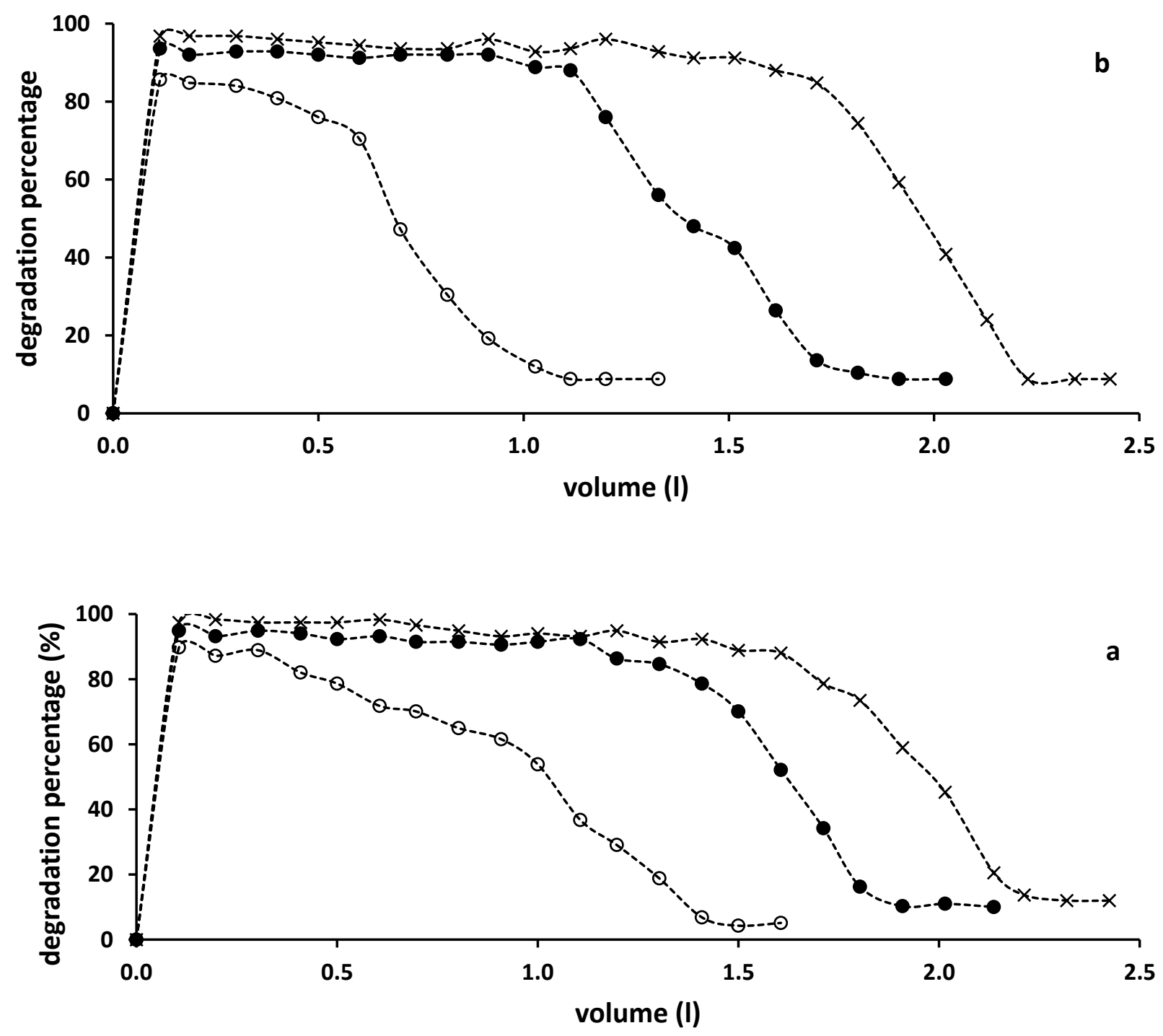

411

412

413 Figure 8 Degradation profiles of p-nitroaniline as percentage (PNA=30 mg/L (a), $100 \mathrm{mg} / \mathrm{L}$

414 (b)) as a function of elution volume and ZVI percentage. ZVI: $1.2(\circ), 2.3(\bullet), 3.4 \%$ (x);

415 column composition (without ZVI): plaster (200.0 g, 41.0\%); water (57.4\%); $\mathrm{CaCO}_{3}(0.2 \%)$;

$416 \quad \mathrm{H}_{3} \mathrm{PO}_{4}(1.4 \%)$

417 As expected, breakthrough points in Bechamp reduction were depending on ZVI amount 418 included in plaster column; PNA concentration seemed have less influence because 419 degradation profiles in Figure 7 (except those with low quantity of ZVI (1.2\%)) were almost 420 superimposable. 
421 From degradation reaction, the amount of PNA reduced to PDA by ZVI (in 2.3 and 3.4\%

422 experiments) was estimated: e.g. $1.6 \mathrm{~L}$ of aqueous PNA solution at $100 \mathrm{mg} / \mathrm{L}$ were treated by

$4233 \mathrm{~g}$ of ZVI, meaning a complete inactivation at around $55 \mathrm{mg}$ of PNA $\left(3.010^{-4} \mathrm{~mol}\right)$ per gram

424 of ZVI $\left(1.810^{-2} \mathrm{~mol}\right)$ moles $)$, or around $2 \times 10^{-2}$ mol PNA per $1 \mathrm{~mol} \mathrm{Fe}(0)$.

\subsubsection{Degradation reaction}

In order to indentify mechanism of PNA reduction in plaster columns, oxidation products

428 from ZVI were searched. Unfortunately the low percentage of metal species in plaster composites did not allow to clearly identify by DRX intermediate species in ZVI oxidation process. Moreover, because of coloured solution for PNA and PDA, Fe(II) or Fe(III) species colorimetric identification in solution was not possible. For these reasons, control experiments were run in order to observe chemical species formed by interaction of ZVI with water. For instance, treating ZVI with $\mathrm{H}_{3} \mathrm{PO}_{4}$, presence of $\mathrm{Fe}(\mathrm{II})$ was detected by colorimetry,

\begin{tabular}{|l|c|c|c|c|}
\hline & $\mathrm{pH}(\mathrm{t}=0)$ & $\mathrm{pH}(\mathrm{t}=48 \mathrm{~h})$ & $\mathrm{Fe}(\mathrm{II})$ test & $\mathrm{Fe}(\mathrm{III})$ test \\
\hline Plaster & 6.92 & 6.87 & n.d. & n.d. \\
\hline Plaster + ZVI & 6.76 & 7.45 & - & - \\
\hline Plaster + ZVI $+\mathrm{CaCO}_{3}+\mathrm{H}_{3} \mathrm{PO}_{4}$ & 6.91 & 7.09 & + & - \\
\hline
\end{tabular}

Table $6 \mathrm{pH}$ values and qualitative colorimetric results for ionic iron species in plaster-based composites soaked in distilled water

In ZVI-containing column, during the addition of PNA solutions, the first volume eluted was 
443 function of volume of organic species added, solution $\mathrm{pH}$ was determined by the presence of

444 specific organic compound (PDA, $\mathrm{pH}=8.07$; $\mathrm{PNA}, \mathrm{pH}=6.10$ for $30 \mathrm{mg} / 1$ aqueous solutions)

445 However, because of instability of Fe(II) species in aqueous solution in presence of dioxygen, 446 at the end of the reduction process, reddish colour of column indicated presence of $\mathrm{Fe}_{3} \mathrm{O}_{4}$ $447 \quad$ species

448 From our experimental results, we cannot exclude or affirme the presence of other iron 449 species such as oxides, hydroxides, or phosphates and make hypothesis on their involvement 450 in reduction reaction.

\subsubsection{Kinetics analysis}

453 Bechamp reduction is a stoichiometric reaction, and not a catalytic one, resulting in a series 454 of parallel reactions, with generation of one or more intermediates and byproducts (Popat \& 455 Padhiyar, 2013). ZVI is "consumed" in redox system (or, from a chemical point of view, oxidated) and/or, probably, passivated during flow of aqueous solutions. However, it has been reported by Noubactep that, in order to minimize the abundance of iron corrosion products in a $\mathrm{ZVI} / \mathrm{H}_{2} \mathrm{O}$ system, the following operations can be undertaken: (i) use the lowest possible Fe(0) loading (e.g. $<5$ g/l); (ii) work under non-disturbed conditions (mixing speed 0 $\min ^{-1}$ ) or low mixing conditions; (iii) used a less reactive material; (iv) work at low temperature (e.g. $15^{\circ} \mathrm{C}$ ). (Noubactep 2009). In our case, if the first point was respected, in

462 order to accelerate kinetics time, we used a special porous plaster with a high flow, which

463 could accelerate reducing agent disruption. Of course, in an environmental application, it 464 would be possible to alternate in PRB porous plaster blocks (in order to absorb more polluted 465 solution) and ZVI-containing compact plaster blocks (in order to act as reducing agent). 466 However, Bechman reaction in PRB seems to be more complex than in solution. In fact, if 
467 contaminant reduction by $\mathrm{Fe}(0)$ occurs and contributes significantly to the process of 468 contaminant removal, this mechanism remains unclear. In fact, it is matter of question in ZVI 469 depolluting systems, if, between the $\mathrm{Fe}(\mathrm{II}) / \mathrm{Fe}(0)$ or $\mathrm{Fe}(\mathrm{III}) / \mathrm{Fe}(\mathrm{II})$ couples, which one is 470 involved in the redox reactions (Noubactep 2008). From our point of view, we checked in 471 batch direct reaction between ZVI and PNA without acid and the reduction occurred with a 472 kinetics depending on ZVI amount. As a consequence, we expected that $\mathrm{Fe}(0)$ would be 473 directly involved in the redox system; however kinetics, in batch and in column were not the 474 same (in column the reaction was instantaneous) suggesting that preliminar treatement with 475 phosphoric acid acted also on ZVI, partially generating $\mathrm{Fe}(\mathrm{II})$ species. It means that $\mathrm{Fe}(\mathrm{II})$ 476 species could be involved in order to accelerate reduction rate, whereas, it remains the 477 question of Fe(II) species stability (excepted in the form of phosphate salt), which is possible 478 only dried or in the absence of dioxygen.

479 If phosphoric acid, reacting with ZVI, can form Fe(II) species, more efficient as redox 480 couple, unfortunately nothing is known on the role of iron phosphate in Bechamp reduction.

481 We can speculate on the possibility that in-situ formed ionic species could coordinate organic 482 molecules in order to favor, by molecular proximity, redox reaction. Between $\mathrm{Fe}(\mathrm{II})$ or $\mathrm{Fe}(\mathrm{III})$ species, the former has preferential affinity to bind nitrogen-containing ligand (Cotton \& 484 Wilkinson, 1988). On this half, studies are actually in progress to evaluate how organic chemical structure could influence redox reaction.

486 Noubactep reported also that corrosion products form an active physical barrier reducing the 487 accessibility of the bare surface of $\mathrm{Fe}(0)$ materials to contaminants getting inactivation of 488 ZVI (Noubactep 2007). It has been suggested, for instance, that "solution decoloration" could 489 occur because of concomitant precipitation of iron hydroxydes (Noubactep 2009a), which 490 absorb organic compounds as we previously observed co-precipitation in case of 491 hydroxyapatite (Lemlikchi, et al. 2014.). From our experience, we cannot totally exclude this 
492 mechanism (Noubactep 2011), whereas PDA recovering, in the first fractions, strongly

493 suggested that redox mechanism was predominant.

494 We observed that, as a function of time, flow through the column increased by $25 \%$.

495 Different hypothesis can made on the interaction between PNA and ZVI. Concerning the

496 flow, two different mechanisms seemed to occur: on one hand, plaster columns were

497 sensitive to percolation, and, as a function of water volume, were fragilized. On the other, in

498 situ formation of insoluble iron species, such as hydroxides or phosphates, in sol or in gel

499 form, could plug the porosities (Noubactep 2008), but with this hypothesis, the flow would be

500 reduced.

501

502

\subsection{Environmental impact and cost}

503 The cost of plaster-based PRB is estimated to be very low and convenient. PDA, the

504 reduction product of PNA, is a still toxic species, but it could be captured on column with 505 special additives (not reported here).

506 An ideal PRB should present the following advantages:

507 i) chemical reactivity, which is related to reactant contact time, depending on kinetics and

508 flow. Chemical reactivity involves also compatibility between reactive species and barrier 509 materials.

510 ii) stability during PRB lifetime in order to minimize lost of efficiency;

511 iii) hydraulic and mechanical performances: PRB permeability has to be higher than aquifer

512 flow in order to not disturb underground flow and not induce polluted flow out of the barrier.

513 The supporting material should also be shaped in blocks in order to easily build PRB and, of 514 course, with good mechanical properties for barrier stability; 
515 iv) reduced environmental impact in order to not increase pollution effects: PBR has to be

516 mainly constituted by inert and non-toxic materials, producing, when possible, non-toxic and 517 harmless by-products;

518 v) cost of PRB building (in terms of materials and construction process as low as possible in 519 order to be economically feasable.

520 Finally, the efficiency of ZVI in plaster based-columns suggest the use of these composite as 521 precast plaster retaining wall blocks in environmental applications.

522

523 4. Conclusion

524 PRB was used to purify water from organic contaminants, such as 4-nitroaniline. Plaster is 525 one of the most used materials in construction industry. It can also be used in PRB, and while 526 it is being made the plaster can incorporate many types of additives. We have included ZVI

527 to make a reactive component with capacity to remove nitro compounds while the water flow 528 passes through the plaster. The use of ZVI as additive in the PRB allows removing the toxic 529 organic compound by reduction of the nitro function to amino functions. To provide a PRB 530 with good flow through properties, the formulation of porous plaster with increased porosity 531 was made possible by the reaction of calcium carbonate with a small amount of phosphoric 532 acid, which causes the evolution of carbon dioxide gas simultaneously with the precipitation 533 of hydroxylapatite effectively making the plaster less water soluble. Thus improved PRB 534 containing plaster, designed porosity and ZVI particles can be developed for use in removal 535 of organic compounds from water. This opens possibilities for the use of PRB in many 536 pollution control technologies where it could be scaled up.

\section{Declarations}

538 Consent for publication 
Not applicable

540

541 Availability of data and materials

542 All data generated or analysed during this study are included in this published article

543

544 Competing interests

545 Authors have not financial and non-financial competing interests on this research field

546

547 Ethical approval

$548 \quad$ Not applicable

549

550 Consent to participate

$551 \quad$ Not applicable

552

$553 \quad$ Funding

554 This research did not receive any specific grant from funding agencies in the public,

555 commercial or not-for-profit sectors.

556

557 Authors' contributions 
$558 \mathrm{MF}$ and PS conceived the study, were in charge of overall direction and planning and were

559 major contributors in writing the manuscript. SB and MF processed experimental data, 560 formulated composites, performed analysis, and drafted the manuscript. FF prepared samples,

561 performed SEM analysis and worked on the manuscript. All authors discussed the results and

562 commented on manuscript.

563

564 Acknowledgements

565 SB is grateful to the Algerian Ministry of Education for the fellowship.

566 The authors thank dr. Farid Errassifi (ILIPACK, PEC Department, Université Toulouse 3

567 Paul Sabatier, Castres, France) for technical assistance in the mechanical strength

568 measurements.

569

570 Abbreviations used

571 PDA, p-phenylendiamine; PNA, 4-nitroaniline; PRB, permeable reactive barrier; ZVI, zero 572 valent iron;

574 REFERENCES

575 Adrien J, Meille S, Tadier S, Maire E, Sasaki L (2016) In-situ X-ray tomographic monitoring of gypsum plaster setting. Cem Concr Res 82:107-116

577 Al-Othman A, Demopoulos G.P (2009) Gypsum crystallization and hydrochloric acid 578 regeneration by reaction of calcium chloride solution with sulfuric acid. $579 \quad$ Hydrometallurgy 96: 95-102 
Béchamp A (1854) De l'action des protosels de fer sur la nitronaphtaline et la nitrobenzine. nouvelle méthode de formation des bases organiques artificielles de Zinin. Ann Chim Phys 42:186-196

CRC Handbook of Chemistry and Physics, 2019, 100th Edition, John Rumble ed. CRC Press. Chernysh Y, Yakhnenko O, Chubur V, Roubik H (2021) Phosphogypsum Recycling: A Review of Environmental Issues, Current Trends and Prospects. Appl. Sci. 11 :1575. https://doi.org/10.3390/app11041575

Cotton F.A, Wilkinson G (1988) Advanced Inorganic Chemistry, John Wiley, New York, pp $709-724$

Diaga Seck M, Van Landeghem M. Faure P, Rodts S, Combes R, Cavalie P, Keita E, Coussot P. (2015) The mechanisms of plaster drying. J Mat Sci 50:2491-2501

Dorathi P.J, Kandasamy P (2012) Dechlorination of chlorophenols by zero valent iron impregnated silica. J Environ Sci 24:765-773

Eljamal O, Mokete R, Matsunaga N, Sugihara Y (2018) Chemical pathways of Nanoscale Zero-Valent Iron (NZVI) during its transformation in aqueous solutions. J Environ Chem Eng. 6:6207-6220. https://doi.org/10.1016/j.jece.2018.09.012

Eljamal O, Thompson IP, Maamoun I, Shubair T, Eljamal K, Lueangwattanapong K, Sugihara y (2020) Investigating the design parameters for a permeable reactive barrier consisting of nanoscale zero-valent iron and bimetallic iron/copper for phosphate removal. J Mol Liq 299:112144. https://doi.org/10.1016/j.molliq.2019.112144

Farooqi ZH, Khalid R, Begum R, Farooq U, Wu Q, Wu W, Ajmal M, Irfan A, Naseem K (2018) Facile synthesis of silver nanoparticles in a crosslinked polymeric system by in situ reduction method for catalytic reduction of 4-nitroaniline. Environ Technol 40:1-30

Fisher RD, Hanna JV, Reesc GJ, Walton RI (2012) Calcium sulfate-phosphate composites with enhanced water resistance. J Mater Chem 22:4837-4846 
605 Gavrilescu M, Demnerová K, Aamand J, Agathos S, Fava F (2015) Emerging pollutants in

606 the environment: present and future challenges in biomonitoring, ecological risks and bioremediation. New Biotechnol 32:147-156

608 Grajales-Mesa S.J, Malina G (2016) Screening reactive materials for a permeable barrier to treat TCE-contaminated groundwater: laboratory studies. Environ Earth Sci 75:772785.

611 Henderson AD. Demond AH (2007) Long-Term Performance of Zero-Valent Iron Permeable 612 Reactive Barriers: A Critical Review. Environ Eng Sci 24:401-423

$613 \mathrm{Hu}$ R, Cui X, Willis Gwenzi W, Wu S, Noubactep C (2018) $\mathrm{Fe} 0 / \mathrm{H}_{2} \mathrm{O}$ Systems for 614 Environmental Remediation: The Scientific History and Future Research Directions. Water SA 10:1739-1755. https://doi:10.3390/w10121739

616 Jaffel H, Jean-Pierre Korb JP, Ndobo-Epoy JP, Morin V, Guicquero JP (2006) Probing 617 Microstructure Evolution during the Hardening of Gypsum by Proton NMR 618 Relaxometry. J. Phys. Chem. B 110: 7385-7391

619 Khalil AME, Eljamal O, Amen TWM, Sugihara Y, Matsunaga N (2018) Scrutiny of 620 interference effect of ions and organic matters on water treatment using supported $\begin{array}{llllll}\text { nanoscale } & \text { zero-valent iron. Environ } & \text { Earth } & \text { Sci } & \text { (2018) } & \text { 77:489. }\end{array}$ https://doi.org/10.1007/s12665-018-7661-6

623 Lajoie-Halova B, Brumas V, Fiallo MML, Berthon G. Copper(II) interactions with non624 steroidal anti-inflammatory agents. III - 3-Methoxyanthranilic acid as a potential $\mathrm{OH}$ inactivating ligand: A quantitative investigation of its copper handling role in vivo. $\mathbf{J}$ Inorg Biochem (2006) 100:362. https://doi:10.1016/j.jinorgbio.2005.12.002

627 Lanzóna M, García-Ruiz PA, 2012. Effect of citric acid on setting inhibition and mechanical 628 properties of gypsum building plasters. Constr Build Mater 28:506-511 
629 Lemlikchi, W, Sharrock P, Fiallo M, Nzihou A, Mecherri MO (2014) Hydroxyapatite and 630 Alizarin sulfonate ARS modeling interactions for textile dyes removal from wastewaters. Procedia Eng 83:378-385

Lewry A.J, Williamson J (1994) The setting of gypsum plaster: part I. The hydration of calcium sulphate hemihydrate, J Mater Sci 29:5279-5284

Maamoun I, Eljamal O, Khalil AME, Sugiharal Y, Matsunaga N (2018) Phosphate Removal Through Nano-Zero-Valent Iron Permeable Reactive Barrier; Column Experiment and Reactive Solute Transport Modeling. Transport in Porous Media 125:1-3. https://doi.org/10.1007/s11242-018-1 124-0

Maamoun I, Eljamal O, Eljamal R, Falyouna O, Sugihara Y (2020) Promoting

aqueous and transport characteristics of highly reactive nanoscale zero valent iron via different layered hydroxide coatings App Surf Sci $506: 145018$.

Maamoun I, Eljamal O, Omar Falyouna, Eljamal R, SugiharaY (2020a) Multi-objective optimization of permeable reactive barrier design for $\mathrm{Cr}(\mathrm{VI})$ removal from https://doi.org/10.1016/j.apsusc.2019.145018

646 Mori T (1982) The Effect of Boric Acid on the Thermal Behavior of Cast Gypsum. Dental Materials Journal 1:73-80

Noubactep C (2007) Processes of Contaminant Removal in " $\mathrm{Fe} 0-\mathrm{H}_{2} \mathrm{O}$ ” Systems Revisited: The Importance of Co-Precipitation Open Environ J. 1:9-13

Noubactep C (2008) A Critical Review on the Process of Contaminant Removal in $\mathrm{Fe} 0-\mathrm{H}_{2} \mathrm{O}$ Systems Environ Technol 29:909-920

652 Noubactep C (2009) An analysis of the evolution of reactive species in $\mathrm{Fe} 0 / \mathrm{H}_{2} \mathrm{O}$ systems. J 
654 Noubactep C (2009a) Characterizing the discoloration of methylene blue in $\mathrm{Fe} 0 / \mathrm{H}_{2} \mathrm{O}$ systems. J Haz Mat 166:79-87

Noubactep C (2011) Aqueous contaminant removal by metallic iron: Is the paradigm shifting? Water SA 37:419-426

Popat V, Padhiyar N (2013) Kinetic Study of Bechamp Process for P-Nitrotoluene Reduction to P-Toluidine. Int J Chem Engineer Appl. 4:401-405

Saadaoui E, Ghazela N, Ben Romdhanea C, Massoudi N (2017) Phosphogypsum: potential uses and problems - a review. Int J Environ Stud 74(4):558-567. http://dx.doi.org/10.1080/00207233.2017.1330582

Sapurina I, Stejskal J (2008) The mechanism of the oxidative polymerization of aniline and the formation of supramolecular polyaniline structures. Polym Int 57:1295-1325

Schabel T, Belger C, Plietker B (2013) A Mild Chemoselective Ru-Catalyzed Reduction of Alkynes, Ketones, and Nitro Compounds. Org Lett 15 :2858-2861

Touze S, Chartier R, Gaboriau H (2004) Etat de l'art sur les barrières perméables réactives (BPR): Réalisations, expériences, critères décisionnels et perspectives; BRGM Orléans, France. $\quad$ www.record-net.org/storage/etudes/02-0330-1A/rapport/Rapport_record020330 1A.pdf

Various authors, 1989. Some nitroarenes. In Diesel and Gasoline Engine Exhausts and Some Nitroarenes. IARC Monograph, vol. 46, IARC Lyon, pp. 188-374; monographs.iarc.fr/iarc-monographs-on-the-evaluation-of-carcinogenic-risks-tohumans-75/

Various authors, 1989a. Chloramphenicol. In Pharmaceutical Drugs. IARC Monograph, vol. 50, IARC Lyon, pp. 169-194; monographs.iarc.fr/iarc-monographs-on-the-evaluationof-carcinogenic-risks-to-humans-71/

Various authors, 1992. Hair Dyes. In Occupation al Exposures of Hairdressers and Barbersand Personal Use of Hair Colourants; Some Hair Dyes, Cosmetic Colourants, 
Industrial Dyestuffs and Aromatic Amines. IARC Monograph, vol. 57, IARC Lyon, pp. 43-118; monographs.iarc.fr/iarc-monographs-on-the-evaluation-of-carcinogenic-risksto-humans-64/

683 Wantanaphong J, Mooney SJ, Bailey EH (2006) Quantification of pore clogging 684 characteristics in potential permeable reactive barrier (PRB) substrates using image 685 analysis. J Contaminant Hydrol 8:299-320 
Figures

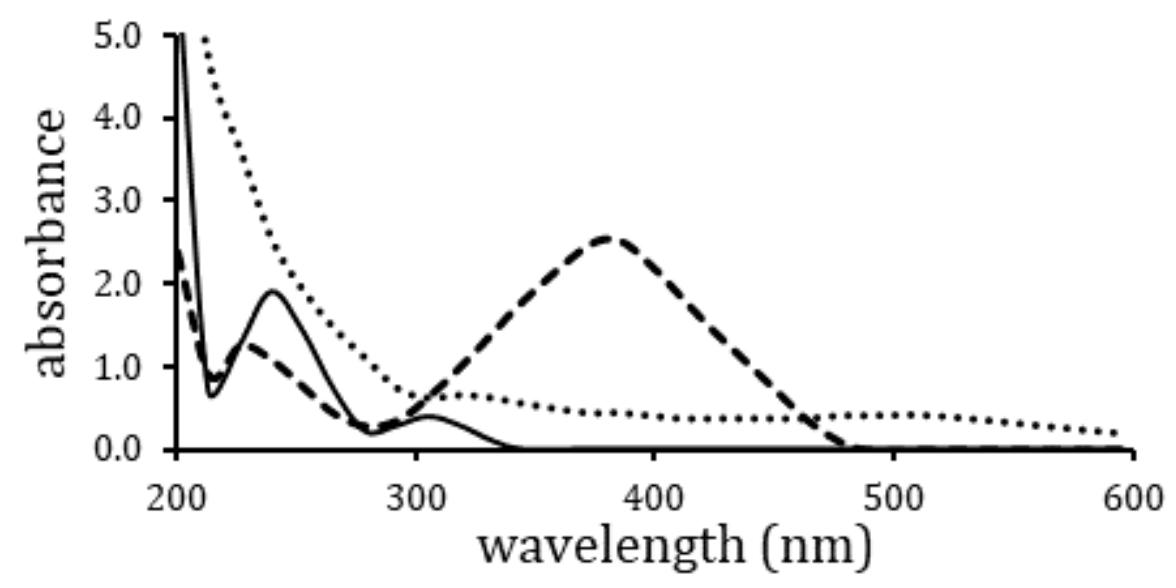

Figure 1

Absorption spectra of PNA (-), PDA (_) and PDA polymerization product (...) in aqueous solutions: $[P N A]=[P D A]=30 \mathrm{mg} / \mathrm{l} ;$ path-length quartz cell $=0.2 \mathrm{~cm}$

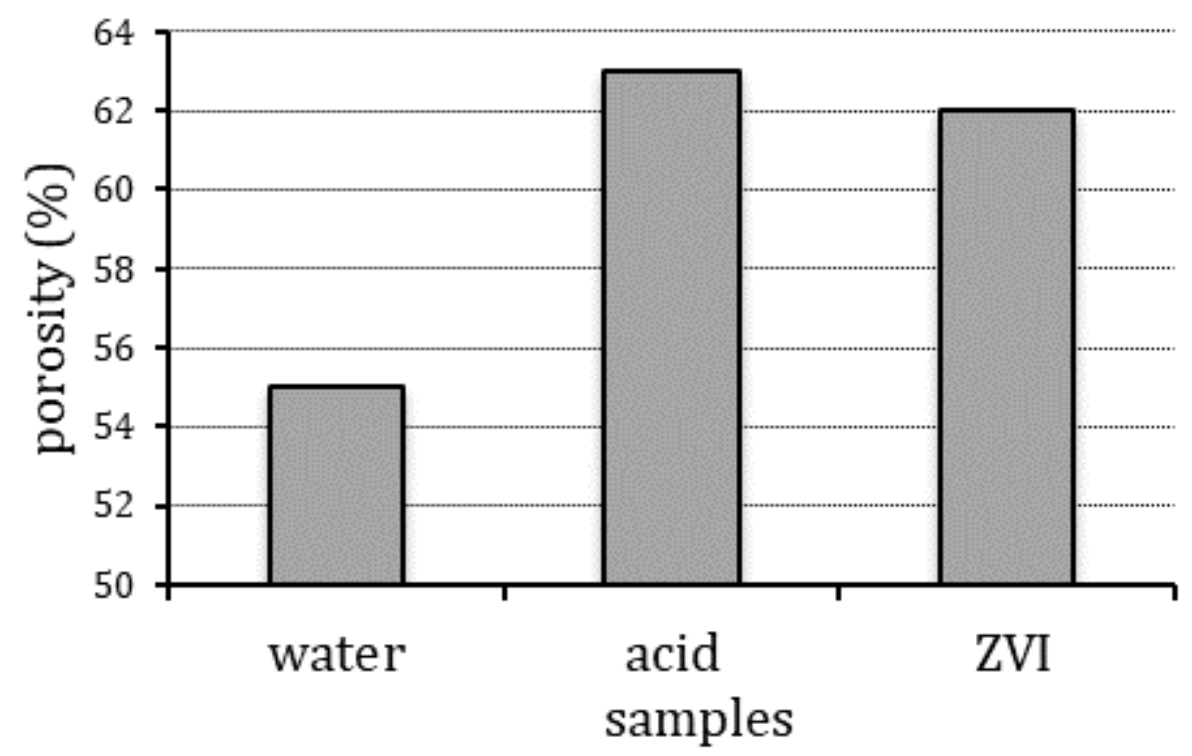

Figure 2

Porosity optimization as a function of different components of BRP (water, phosphoric acid and ZVI) plaster (50.0 g, 40.0\%); water (56.0\%); $\mathrm{CaCO}$ (0.2\%); H3PO4 (0.2\%) Plaster samples were observed by scanning electron microscopy (SEM) Zeiss Supra 55VP. 


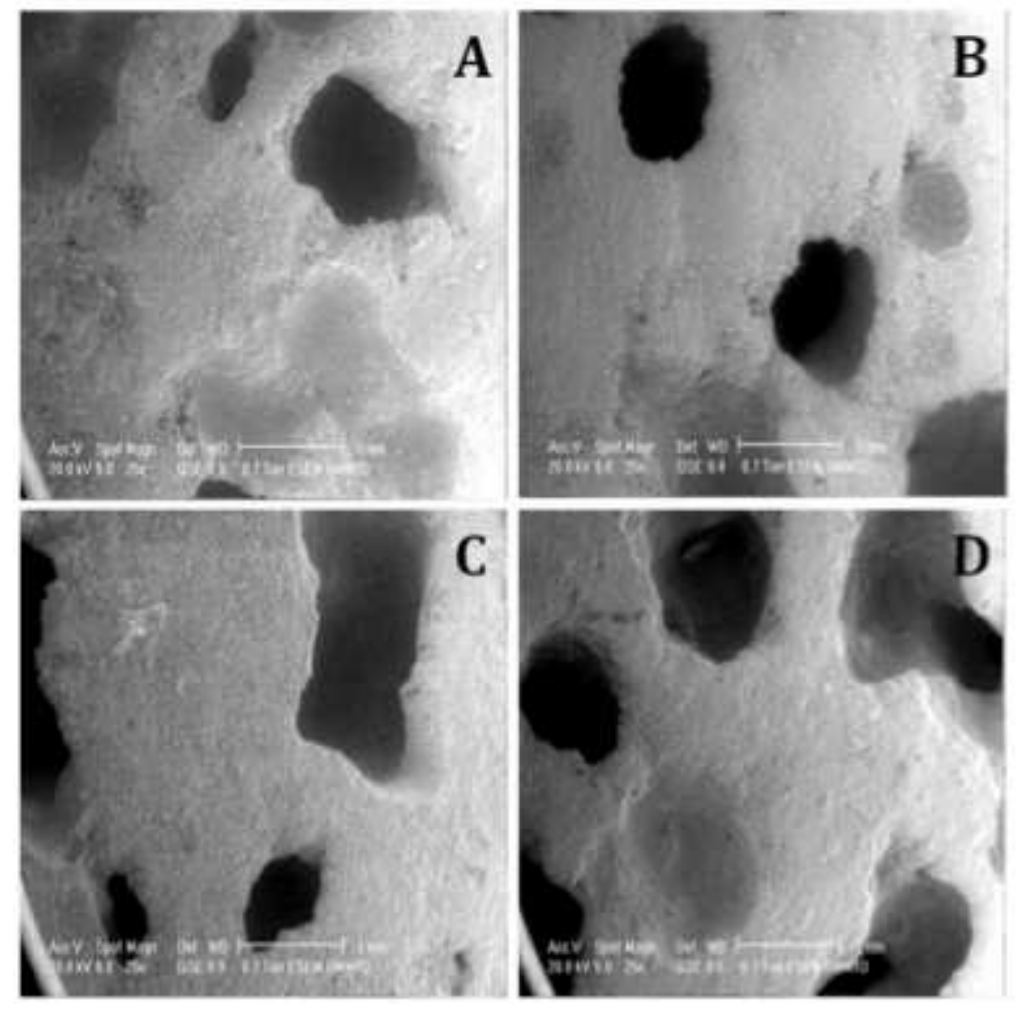

Figure 3

SEM photographs showing a view of porogen-containing hardened gypsum samples, prepared with a water-to-plaster ratio of 0.7 , as a function of carbonate amounts (with $1.1 \%$ phosphoric acid, $\mathrm{w} / \mathrm{w}$ ). CaC03: $A=0.2 \%, B=0.5 g, C=0.7 \mathrm{~g}, D=0.9 \%(w / w)$; length scale bar is $1 \mathrm{~mm}$ and magnification $\times 25)$ 

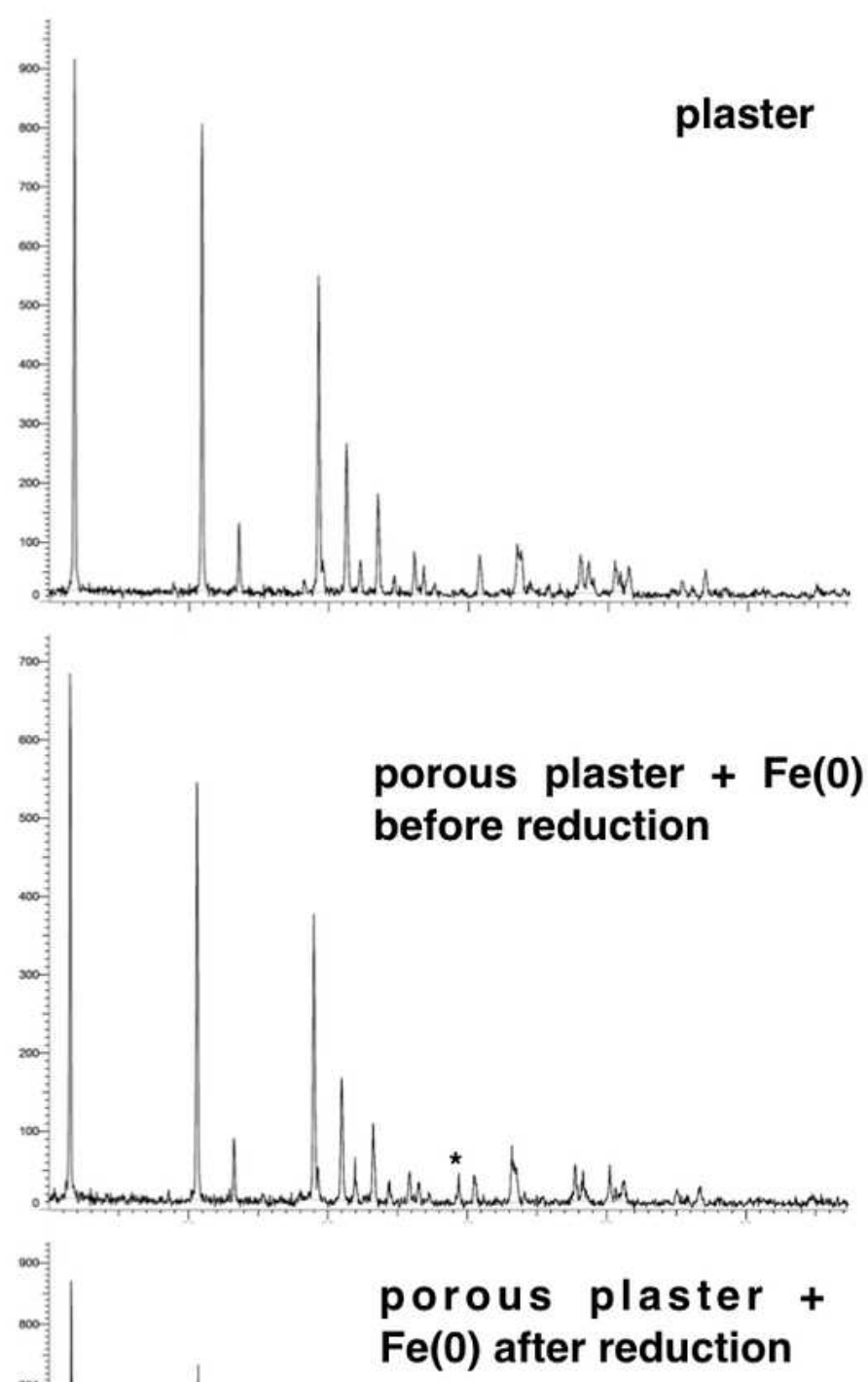

Figure 4

DRX of plaster composites, with and without $\mathrm{Fe}(0)$, before and after PNA reduction. Composites were formulated as in Tables 1 and 4 


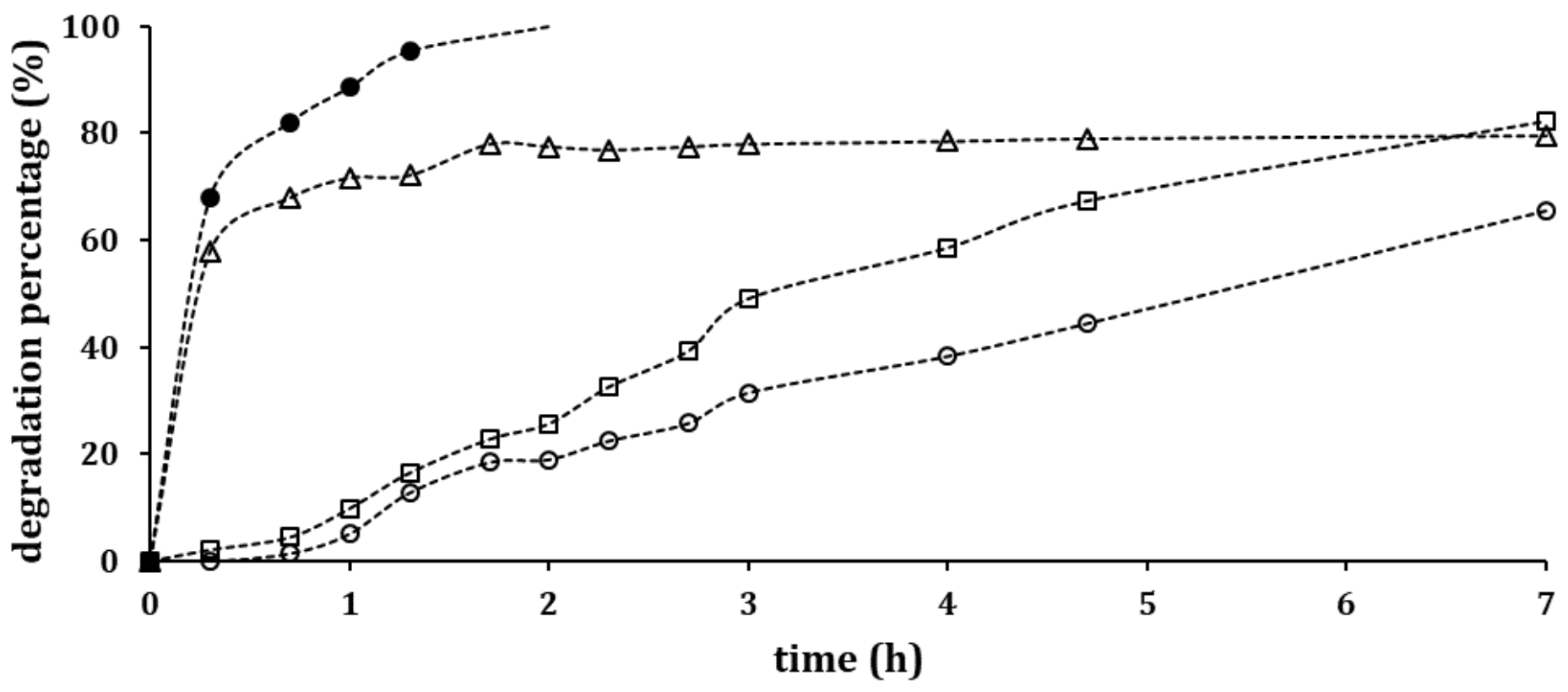

Figure 5

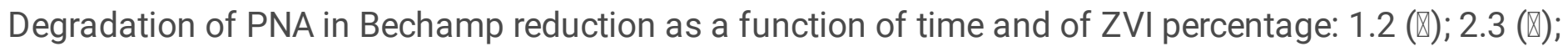

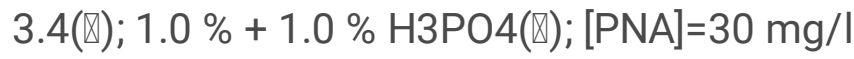

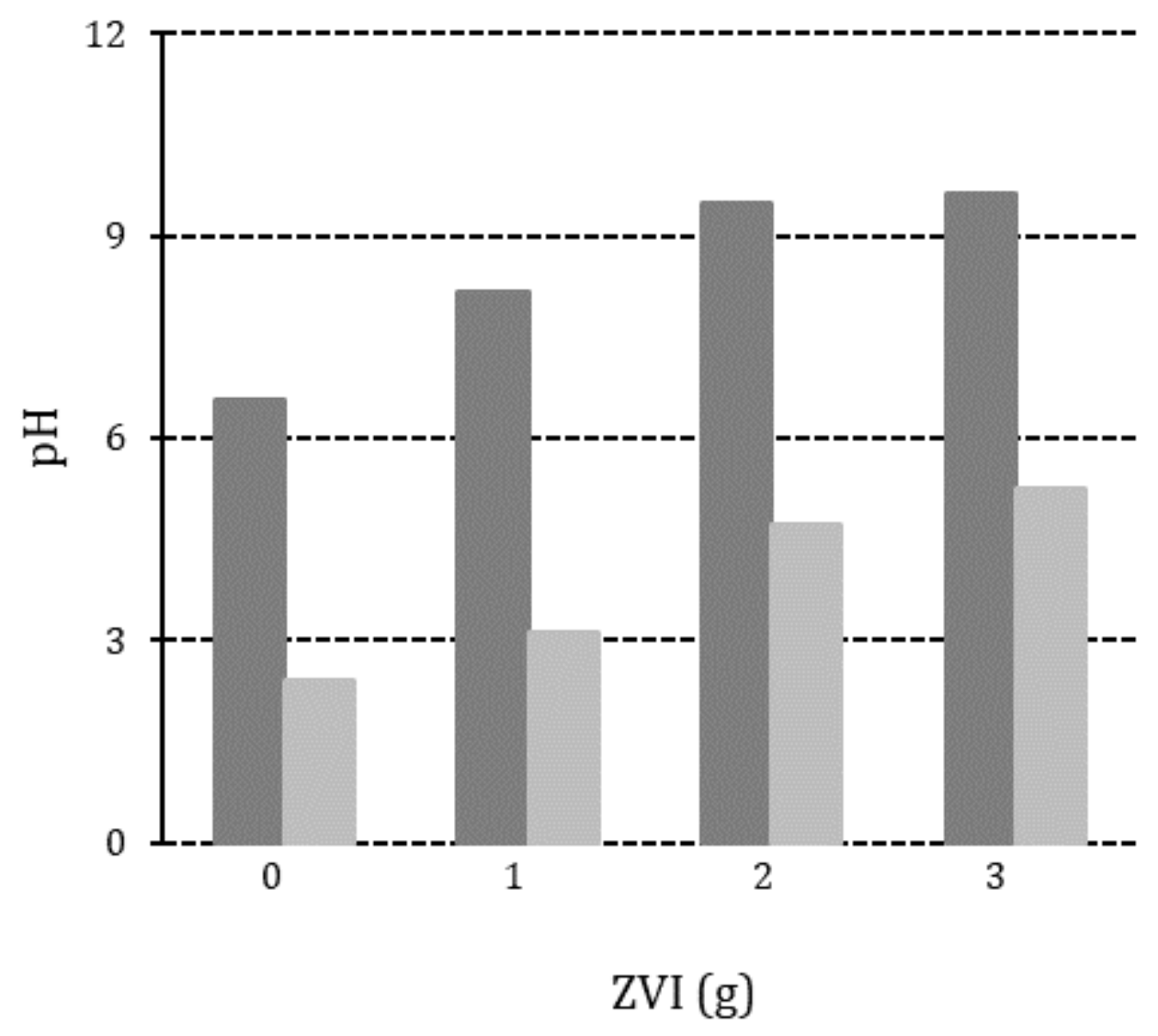

Figure 6 
Final $\mathrm{pH}$ values of solutions in batch Bechamp reduction after 7 hours, as a fonction of $\mathrm{ZVI}$ : without acid (dark grey); with $1 \%$ H3PO4 (light grey)

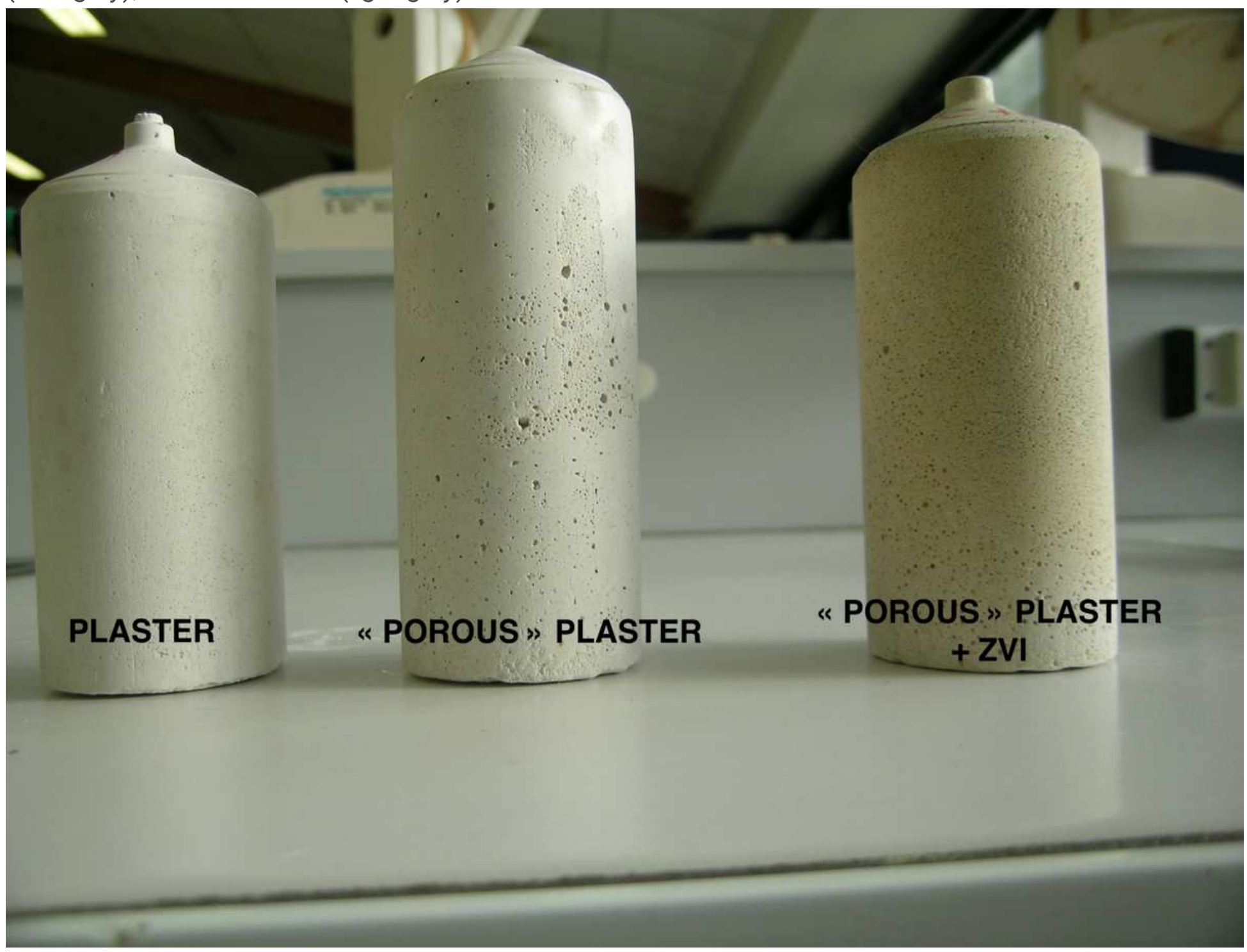

\section{Figure 7}

Plaster columns. Column composition: plaster (50.0 g, 41.0\%); water (57.4\%); CaCO3 (0.2\%); H3PO4 $(1.4 \%)$; ZVI $(2.3 \%)$ 

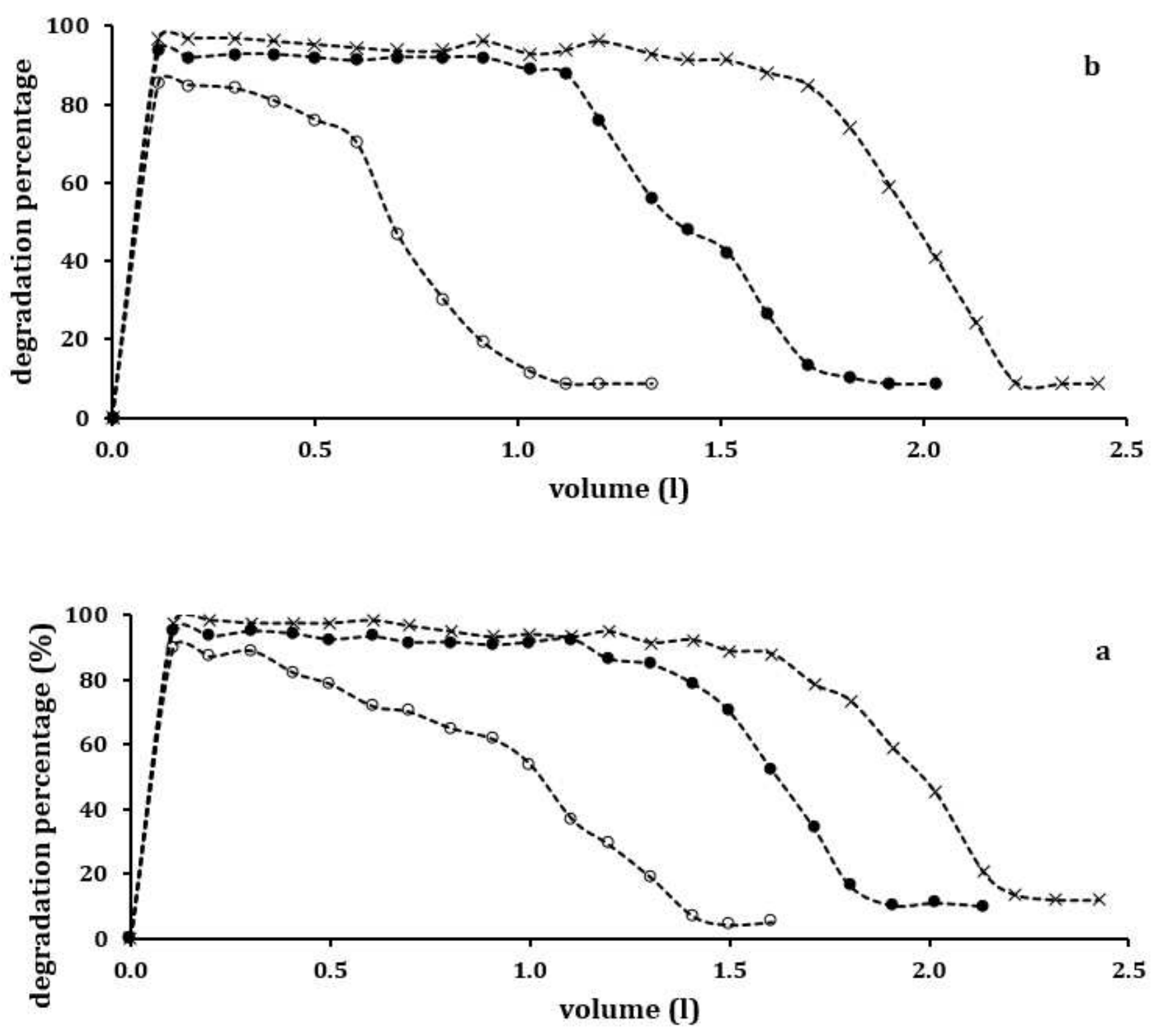

Figure 8

Degradation profiles of p-nitroaniline as percentage (PNA $=30 \mathrm{mg} / \mathrm{L}(\mathrm{a}), 100 \mathrm{mg} / \mathrm{L}(\mathrm{b})$ ) as a function of

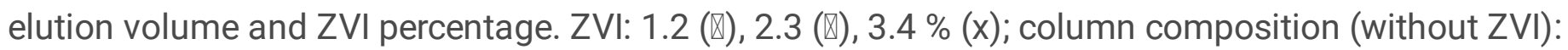
plaster (200.0 g, 41.0\%); water (57.4\%); CaCO3 (0.2\%); H3PO4 (1.4\%)

\section{Supplementary Files}

This is a list of supplementary files associated with this preprint. Click to download.

- GraphicalAbstract.jpg 